\title{
Giving College Credit Where It Is Due: Advanced Placement Exam Scores and College Outcomes Faculty Research Working Paper Series
}

\section{Jonathan Smith}

College Board

Michael Hurwitz

College Board

\section{Christopher Avery}

Harvard Kennedy School

\section{May 2015}

\section{RWP15-021}

Visit the HKS Faculty Research Working Paper Series at:

https://research.hks.harvard.edu/publications/workingpapers/Index.aspx

The views expressed in the HKS Faculty Research Working Paper Series are those of the author(s) and do not necessarily reflect those of the John F. Kennedy School of Government or of Harvard University. Faculty Research Working Papers have not undergone formal review and approval. Such papers are included in this series to elicit feedback and to encourage debate on important public policy challenges. Copyright belongs to the author(s). Papers may be downloaded for personal use only. 


\title{
Acknowledgements
}

This research reflects the views of the authors and not their corresponding institutions. At least one co-author has disclosed a financial relationship of potential relevance for this research. Further information is available online at http://www.nber.org/papers/w21147.ack

(C) 2015 by Jonathan Smith, Michael Hurwitz, and Christopher Avery. All rights reserved. Short sections of text, not to exceed two paragraphs, may be quoted without explicit permission provided that full credit, including (C) notice, is given to the source.

\begin{abstract}
We implement a regression discontinuity design using the continuous raw Advanced Placement (AP) exam scores, which are mapped into the observed 1-5 integer scores, for over 4.5 million students. Earning higher AP integer scores positively impacts college completion and subsequent exam taking. Specifically, attaining credit-granting integer scores increases the probability that a student will receive a bachelor's degree within four years by 1 to 2 percentage points per exam. We also find that receiving a score of 3 over a 2 on junior year AP exams causes students to take between 0.06 and 0.14 more AP exams senior year.
\end{abstract}




\section{Introduction}

Stagnant completion rates and increasing time-to-degree (Bound, Lovenheim, and Turner, $2010 ; 2012$ ) in a time of high unemployment, budgetary crises, and increasing federal grant aid (College Board, 2013a) have put colleges under increased public scrutiny. Inadequate preparation for college is one factor behind the criticisms of college completion, but it is not the only factor. Finishing a bachelor's degree on time generally requires a student to complete at least 120 credit hours within four years. To accomplish this, a student might take five courses per semester, spread over eight semesters. Timely completion requires students to fulfill the coursespecific requirements of their chosen major, as well as any general education coursework necessary for the awarding of a bachelor's degree. For many students, neatly cobbling together a postsecondary curriculum that satisfies both graduation and major requirements within 120 credit hours is challenging. So difficult is this task that in 2011, 33 U.S. governors endorsed a report authored by the Complete College America organization that identified excessive college course taking as one of the five leading causes of the nation's college completion crisis. ${ }^{1}$

One potential way to ameliorate this problem is to give students the opportunity to earn college credit while still in high school, which is typically accomplished either through dual enrollment or Advanced Placement (AP) programs. ${ }^{2}$ These widely accepted courses allow students to earn credit and placement towards college graduation and to bypass introductory courses while freeing up time to fulfill both major and general education requirements. ${ }^{3}$ In theory, students who take advantage of these colleges' AP credit and placement policies may

\footnotetext{
${ }^{1}$ Upon receiving bachelor's degrees, many students will have taken nearly 15 more credits than the minimum required for such a degree. Time is the Enemy (2011). College Completion America. Retrieved from http://www.completecollege.org/docs/Time_Is the Enemy_Summary.pdf.

${ }^{2}$ Other solutions exist, including student facing solutions (e.g. better preparation and college match) and college facing solutions (e.g. better professors, smaller classes, fewer requirements, and financial aid).

${ }^{3}$ As of 2012, nearly four-fifths of four-year public and private not-for-profit colleges had AP credit policies in place (IPEDS, 2012).
} 
have an increased likelihood of completing college within a certain number of years after high school graduation.

While taking an AP exam is a strong signal of academic ability, it is not a guarantee of post-secondary academic success. About 16 percent of AP exam-takers do not attend four-year postsecondary institutions and less than half (41 percent) complete bachelor's degrees within four years of high school graduation (see discussion of Table 1 below in Section 3). Thus, it is plausible to conduct empirical analyses to study the effect of success on an AP exam on such outcomes as completion of a bachelor's degree within four (or five or six) years of high school graduation. We believe that this paper is the first to identify the causal effect of receiving college credit while in high school on such outcomes.

To evaluate the impact of early receipt of college credit, we exploit previously unavailable data on the underlying AP exam continuous raw scores that map into the 1-5 integer (scaled) scores, where a 5 is the highest possible score. ${ }^{4}$ Availability of continuous data lend themselves to a sharp regression discontinuity design whereby we compare nearly identical students, as demonstrated with both density tests and covariate balancing tests, just above and just below the thresholds of each scaled score as well just above and below the scores for which students would receive credit at their chosen postsecondary institutions. The student just above the threshold may receive the associated benefits resulting from earning a higher AP exam score, which may include improved college admissions outcomes, advanced placement, credit, completion, or even the psychological benefits of positive affirmation. We focus much of the discussion of results on Biology, Calculus AB, English Language and Composition, English Literature and Composition, U.S. Government and Politics, and U.S. History, the six largest

\footnotetext{
${ }^{4}$ According to the College Board, the 1-5 scores can be interpreted as follows in terms of college credit, respectively: no recommendation, possibly qualified, qualified, well qualified, and extremely well qualified.
} 
volume AP exams. These six exams encompass the four major high school curricular strands of humanities, social sciences, natural sciences and mathematics.

The paper proceeds as follows. Section 2 summarizes the history of the Advanced Placement program and results of past research on the effects of the program. Section 3 describes our empirical hypotheses and the data we use to test them. Section 4 outlines the framework for our empirical methodology. Section 5 presents empirical results. Section 6 concludes.

\section{Background and Literature Review}

The AP program dates back to the 1950 s and was born partially to remedy "conspicuous waste through unneeded repetition in the subjects of English (composition and literature), history, sciences and foreign languages" (Lacy, 2010, p.28). Originally concentrated in well-todo high schools, the AP program underwent rapid expansion during the last quarter of the 20th century, and by the mid 1990's nearly half of U.S secondary schools offered AP coursework (Lacy, 2010). By the 2009-10 academic year, 71 percent of all U.S. public high schools had students participating in the AP program, and these schools enrolled 91 percent of public high school students (Theokas and Saaris, 2013). AP participation rates have been steadily rising as well, from more than 660,000 in the 2004 high school graduation cohort to approximately 940,000 for the 2009 cohort. ${ }^{5}$ These AP participants tend to be academically stronger than the typical college-aspiring students, with composite SAT (Math+Critical Reading) scores of approximately 1136 on the Math and Critical Reading sections, which corresponds to 71 st percentile among the population of students from the 2004 thru 2009 cohorts who took the SAT.

5 These numbers include both private and public school students as well as international students. 
The exact number of AP exams has varied over time, as some exams were retired due to low participation rates and new exams were introduced as a result of high student demand. In this research study, we consider 34 distinct subject exams, while focusing on the six most popular (See Appendix 1 for details on exams).

\subsection{Scoring}

As previously discussed, AP exams are scored on an integer scale of 1-5, where a score of 5 indicates that a student is "extremely well qualified" to receive college credit and a score of 3 suggests that the student is qualified to receive college credit. The minimum scaled score required for college credit varies by college and by AP exam subject. Across the students who take the six major exams, approximately 94 percent of the students attend a college that gives credit for the exams and conditional on giving credit, approximately 58 percent of students attend a college that require a 3, 38 percent require a 4 , and 4 percent require a $5 .^{6}$

Underlying this scaled score is a continuous raw score which is a composite of the student's performance on both the multiple choice and free response sections of the AP exams. This raw score is never observable to the student or college, and for a typical AP exam might range from 0 to about 150 , though the range of raw scores within a scale score varies across subjects and also across years for a given subject.

\subsection{Literature Review}

A series of previous studies demonstrate a strong positive correlation between AP participation, AP exam scores and subsequent academic performance across a range of measures including college attendance (Chajewski, Mattern, and Shaw, 2012) and success in subject performance (Patterson and Ewing, 2013), overall performance (Shaw, Mattern, and Marini,

\footnotetext{
${ }^{6}$ More details on the distribution of policies in the data can be found in Appendix Table 1 and college-specific policies are maintained at https://apscore.collegeboard.org/creditandplacement/search-credit-policies.
} 
2012), and college completion (Morgan and Klaric, 2007; Dougherty, Mellor, and Jian, 2008; Hargrove, Godin, and Dodd, 2008 ; Mattern, Marini and Shaw, 2013). ${ }^{7}$ These studies show that AP is a useful tool in identifying students who demonstrate potential for earning college credit/placement. Though many of these studies convincingly demonstrate the predictive power of AP exams, even after controlling for extensive sets of covariates, they do not estimate the causal effects of taking an AP exam or achieving certain scores.

There have been some promising efforts to address the lingering causal research questions. For example, Jackson (2010) shows that students who are given cash to take and perform well on AP exams are more likely to have higher SAT scores and matriculate in college. While Jackson convincingly addresses the effect of AP course participation in Texas, he is unable to disentangle the effects of achieving relatively higher AP exam scores beyond traditional methods of controlling for observables. Similarly, other papers use a selection on observables design but they note that any unobservable that is correlated with AP exam score may confound the estimates (e.g. Murphy and Dodd, 2009; Long, Conger, and Iatorala, 2012). ${ }^{8}$ Our paper is the first study to isolate the causal impacts of achieving certain benchmark AP exam scores on student outcomes for those who have taken the exams.

\section{Data, Descriptive Statistics, and Empirical Hypotheses}

This paper uses student-level data from the 2004-09 graduating high school cohorts collected from two main sources, College Board (CB) data on AP examinees and National Student Clearinghouse (NSC) data. CB maintains a database of all students who take at least one AP exam. This database contains not only the students' AP exam scores on the 1-5 integer scale,

\footnotetext{
${ }^{7}$ There is a similar line of research on dual enrollment. For example, see Karp et al. (2007).

${ }^{8}$ There are currently some randomized AP evaluations underway, which will be very informative, but they are limited in their scope of exams and populations (Conger, Long, and McGhee, 2014).
} 
but their underlying continuous scores on most exams taken between 2004 and 2009. From these two pieces of information, we identify the exact continuous scores that sharply form the boundaries of the scaled scores. ${ }^{9}$ In addition to student performance on each AP exam, the CB data also contain a host of student demographic information, such as a student's gender, race/ethnicity, and parental income. ${ }^{10}$

CB data are merged with the NSC data. As of 2014, over 3,600 postsecondary institutions participate in NSC, which collects postsecondary enrollment information on more than 98 percent of students enrolled in U.S. postsecondary institutions. Data from the NSC allow us to track a student's postsecondary trajectory including enrollment and degree completion through 2013. Thus, we are able to track the 2009 cohort of high school graduates through up to four years of college enrollment and to track earlier cohorts of high school graduates for at least five years after high school graduation. As a simple measure of four-year college quality, we append to our data the average standardized test scores (ACT and SAT) of incoming students reported to the Integrated Postsecondary Education Data System (IPEDS). ${ }^{11}$

Finally, we merge data on AP credit-granting policies to the colleges at which students enroll. These data come from the College Board administered Annual Survey of Colleges (ASC), which is administered annually to nearly 4,000 colleges. In the 2004 and 2005 surveys, the ASC collected information on the minimum AP exam scores on 34 exams for which colleges award

\footnotetext{
${ }^{9}$ Data on raw scores are available only for exams taken during the 2003-04 school year or later. Therefore some AP test takers, particularly in the 2004 and 2005 cohorts, will not have raw scores that can be mapped to their scaled scores. Any exam without an accompanying raw score is removed from our analyses,

${ }^{10}$ Parental education and income are collected on the SAT registration forms, and so some AP test takers who did not participate in the SAT will have missing demographic information. Even among SAT participants, some students fail to respond to these questions.

${ }^{11}$ To estimate average composite SAT scores, we add the 25 th and 75 th percentiles of the Math and Critical Reading sections, as reported by IPEDS, and divide by 2. For colleges that only report ACT scores to IPEDS, we use an SAT conversion table found at http://research.collegeboard.org/sites/default/files/publications/2012/7/researchnote-200940-act-sat-concordance-tables.pdf
} 
credit. ${ }^{12}$ Historically, college-level AP policies change very little from one year to the next. For example, less than one-tenth of one percent of college-by-subject minimum scores differed between the 2004 and 2005 surveys. Therefore, we match the 2005 college-level policies to postsecondary institutions attended by the 2006-2009 high school graduation cohorts with the data-informed assumption that any noise such matching introduces is likely to be minimal. ${ }^{13}$

\subsection{Summary Statistics}

We present summary statistics on all students appearing in our sample in Table 1, as well as students participating in the six most-represented AP exams in our sample. The first set of columns show that females constitute the majority of AP examinees and that slightly less than two-thirds of sampled students identified as white. Panel B of Table 1 shows the distribution of AP exam scores among the sampled students. On average, the sampled students took 2.64 AP exams for which we had the underlying raw scores and received 0.48 (18 percent) scores of 1 ; 0.59 (22 percent) scores of 2; 0.67 (25 percent) scores of 3; 0.53 (20 percent) scores of 4; and 0.37 (15 percent) scores of 5. Most - 84 percent - of these students ultimately attend a four-year postsecondary institution and 41 percent obtained bachelor's degrees within four years of high school graduation.

Demographically, participants in the six most popular AP exams mirror the typical AP examinee, an exception being Calculus $\mathrm{AB}$ where slightly more than half of participants are male. Some of these APs exhibit sharp differences from each other in their scoring distributions. For example, there is unusual variation in the scaled integer scores on the Calculus AP exam nearly half of students receive the lowest or highest scores of 1 and 5 ( 25 percent and 21 percent

\footnotetext{
${ }^{12}$ There exists no data on minimum scores for Chinese, Italian Language and Culture, and Japanese Language and Culture.

${ }^{13}$ Among subjects for which survey respondents indicated minimum scores in both 2004 and 2005, there were absolutely no reported changes in the credit-granting minimum scores.
} 
of Calculus $\mathrm{AB}$ participants receive scores of 1 and 5 respectively) whereas only about one-sixth of exam-takers receive these extreme scores on the English Literature exam (9 percent and 7 percent of English Literature participants). Academically, participants in these "major" subject exams appear to be stronger than all AP exam-takers, with about 90 percent of participants enrolling at a four-year college and 70 percent receiving bachelor's degrees within six years of high school completion.

\subsection{Empirical Hypotheses}

We use the summary statistics from Table 1 to direct our choice of empirical hypotheses for this paper. As we describe in more detail in Section 4, our analysis is based on a regression discontinuity approach, comparing students with raw scores just above and below the threshold for scores in the 1 through 5 range on a given AP exam. We wish to focus on comparisons of students with similar raw scores on a given exam, but where those just above a particular threshold qualify for college credit and those just below that threshold do not qualify for college credit.

Our first hypothesis is simply that students will be attracted to colleges that offer credit for the particular scores that they achieve. Though students who take more than one exam may face diluted incentives with regard to their score on a particular exam, this incentive would still apply (to some degree) for each and every AP exam that they take.

(H1) Students will be more likely to attend colleges that provide credit for the AP exam scores that they receive.

This hypothesis is also important to the econometric approach of our subsequent analyses. If students systematically vary their choice of colleges based on the combination of their AP exam scores and credit policies of colleges, then we would have to regard the choice of 
college as endogenous. In this scenario, we might conflate effects from college quality with the effects of receiving credit.

However, we also note that 11 th grade AP exam-takers likely have much more ability to adjust their college plans after learning their exam scores than do 12th grade AP exam-takers. Most students who take an AP exam as high school seniors will have graduated from high school, selected a four-year college and paid a deposit to that college by the time that they receive their scores in the middle of the summer. At this time, it is too late to apply to additional four-year colleges, for colleges to change admission decisions from the past spring, or for students to enroll at a college after previously rejecting its offer of admission.

Since Table 1 indicates that completion of a bachelor's degree (especially within four years of high school graduation) is quite uncertain for this population of students, it seems appropriate to focus on degree completion as an outcome of interest. Each AP credit that counts towards requirements for college graduation may enable a student to reduce course load and still graduate on time in four years. Hypothesis (H2) concerns this direct effect:

(H2) Achieving an AP exam score that counts for college credit promotes the completion of post-secondary degrees.

Hypothesis (H2) is silent on the mechanism behind credit promoting completion. For example, students may face a reduced course load or they may have the same course load, but a different composition of courses.

There are several additional channels by which an increase in AP exam score could promote postsecondary educational attainment. Each of these channels corresponds to a distinct empirical hypothesis, which we enumerate below. 
(H3) Achieving a relatively high AP exam score provides a psychological boost to students and thus promotes their subsequent academic performance.

In recent years, it has become increasingly popular for students to take AP exams prior to the senior year of high school. Success on an AP exam prior to the senior year can affect future performance in several additional ways.

(H4) Achieving a relatively high AP exam score prior to the senior year of high school may encourage students to continue taking advanced courses and AP exams in subsequent years in high school.

One factor opposing hypothesis (H4) is that students typically select high school courses in the late winter or early spring for the following school year. Once again, since this predates the scoring of that year's AP exams for junior exam-takers, it may not be feasible in all cases for a student to change enrollment in AP courses for the next year after receiving AP exam scores for the previous school year.

(H5) Achieving certain AP exam scores prior to the senior year of high school may promote future enrollment at selective colleges.

(H5a) Achieving an AP exam score prior to the senior year of high school may encourage students to adopt more ambitious strategies in the college application process, thereby making them more likely to apply to more selective colleges than they would have otherwise.

(H5b) Achieving an AP exam score prior to the senior year of high school may improve the chances of admission to a particular selective college, conditional on applying to that college. 
Several of these hypotheses, and in particular (H5a), may be especially pertinent for lowincome students. Hoxby and Avery (2013) find that high achieving low-income high school students are quite unlikely to apply to selective colleges. Further, Pallais (2013) concludes that the application choices of low-income students are highly sensitive to small changes in the cost of sending ACT scores to colleges. So it is natural to hypothesize that the college application choices of talented low-income students may also be strongly influenced by a marginal change in scaled score on a particular AP exam.

Hypotheses (H1) to (H5), which consider college choice, clearly overlap to some degree. Fortunately, because we have information on (1) AP credit policies at each college; (2) AP exam participation and scores for each student all through high school; (3) the set of colleges where each student sends SAT scores; (4) college enrollment for each student by semester and year, we can conduct a series of empirical tests that disentangle this overlap and enable us to evaluate each hypothesis separately.

\section{Empirical Methodology}

We consider three distinct sets of outcomes in our empirical analysis as listed below:

- College Completion Outcomes: ${ }^{14}$

o Attains a Bachelor's Degree in Four Years

o Attains a Bachelor's Degree in Six Years

- College Application and Enrollment Outcomes:

o Number of SAT Score Sends (proxy for application)

o Attends a Four-Year College First (on-time ${ }^{15}$ )

\footnotetext{
${ }^{14}$ We include students who earn bachelor's degrees through August four and six years beyond high school graduation.

${ }^{15}$ In this paper, we refer to on-time as beginning at a four-year college within 180 days of high school graduation.
} 
o Mean SAT of First College Attended (four-year colleges only)

- Subsequent AP Exam Taking and Performance for Junior Year AP exam-takers:

o Total AP Exams Taken Senior Year

o Total Scores of 3 or Higher Senior Year

o Total Scores of 4 or Higher Senior Year

While we believe that it is mechanically (nearly) impossible for the result of an AP exam taken by a high school senior to influence that student's choice of college applications and enrollment choices for the following fall, we still perform analyses of these outcome variables to verify that conjecture. However, since students do not take AP exams after graduating from high school, our analysis for the third set of outcome variables - AP exam taking in subsequent academic years - is limited to students who complete an AP exam in one year and then return to high school the following year. Technically, we could perform analyses for AP exams results in all grades prior to the senior year of high school, but since it is relatively rare for 9th and 10th graders to take an AP exam, we limit our attention to the results of AP exams for high school junior and seniors.

\subsection{Unidimensional Framework}

For our first set of analyses, we examine the effect of a marginal change in score on a single AP exam on future outcomes. Each student $i$ on AP exam $\mathrm{j}$ receives a continuous score $C_{i j}$. This continuous score maps into the scaled score, $T_{i j}$ as follows:

$$
T_{i j}=\left\{\begin{array}{c}
1 \text { if } C_{i j}<t_{j}^{2} \\
2 \text { if } t_{j}^{2} \leq C_{i j}<t_{j}^{3} \\
3 \text { if } t_{j}^{3} \leq C_{i j}<t_{j}^{4} \\
4 \text { if } t_{j}^{4} \leq C_{i j}<t_{j}^{5} \\
5 \text { if } t_{j}^{5} \leq C_{i j}
\end{array}\right.
$$


where $t_{j}^{n}$ are the thresholds for each scaled score $n$ on exam $j$. For each value of $n \in\{2,3,4,5\}$, we create two variables. The first is the forcing variable:

$$
\operatorname{Dist}_{i j n}=C_{i j}-t_{j}^{n}
$$

which captures how far student $i$ 's score on exam $j$ is from threshold $n$. A Dist $t_{i j n} \geq 0$ implies that the student has a scaled scores of at least an $n$. This leads to the second variable for each value of $n$, the dichotomous threshold variable:

$$
\text { Boundary }_{i j n}=\left\{\begin{array}{l}
1 \text { if } \text { Dist }_{i j n} \geq 0 \\
0 \text { if } \text { Dist }_{i j n}<0
\end{array}\right.
$$

After generating these variables, our basic empirical framework is shown by the standard regression discontinuity equation presented in equation (1), where $X_{i j}$ is a vector of fixed effects for the student's year of high school graduation and the high school year in which they participated in AP exam $j$

$$
\text { Outcome }_{i j n}=\alpha_{0}^{n}+\alpha_{1}^{n} \text { Boundary }_{i j n}+\alpha_{2}^{n} \text { Dist }_{i j n}+\alpha_{3}^{n} \text { Boundary }_{i j n} \times \text { Dist }_{i j n}+X_{i j}+\varepsilon_{i j n}
$$

We are primarily interested in the estimate of $\alpha_{1}^{n}$, which is the coefficient on Boundary $y_{i j n}$ that represents the discontinuous effect of being above the AP scaled $n$ threshold on the outcome of interest. In practice, we separately estimate the effects of each scaled threshold. We also define the forcing variable to represent the distance between the student's raw AP exam score in subject $j$ and the score above which the student would have been eligible to receive credit at her chosen college.

The dependent variable in equation (1) is an indicator variable for the following outcomes for each threshold $n$. In order to capture trends in the forcing variable that exist on 
either side of the boundary, we fit a local linear regression with a triangular kernel. The triangular kernel puts more weight on the observations closest to the threshold. In all regressions, we estimate the optimal bandwidth using the method suggested by Imbens and Kalyanaram (IK) (2012). ${ }^{16}$

As with any regression discontinuity design, students just below an AP scaled threshold are expected to have identical college and degree aspirations compared to students at or just above the AP scaled threshold. Researchers who use test cut scores as forcing variables in regression discontinuity designs often worry about score manipulation as a potential source of bias (Schochet et al., 2010). Score manipulation might occur if students know exactly how many questions they need to answer correctly in order to receive a certain score. Since students are neither informed of how the exams are scored nor are they provided with their own raw scores, manipulation would be impossible in this context. Nevertheless, we address and discount this threat by showing that the density of scores is continuous in the vicinity of the thresholds through density tests in the spirit of McCrary (2008). Second, we run covariate balancing tests with similar specifications to equation (1), but using a covariate as the outcome. This allows us to confirm that students just below the thresholds are observationally similar to students just above the thresholds.

\subsection{Multidimensional Framework}

The parameter estimate, $\alpha_{1}^{n}$, in equation (1) allows us to estimate the discontinuous jump in the outcome measure from achieving one additional credit-granting AP exam score. For the typical AP exam-taker, this parameter estimate likely understates the true impact of the AP program. This is because more than 62 percent of AP exam-takers from the 2004 thru 2009 high

\footnotetext{
${ }^{16}$ We test the sensitivity to bandwidth and kernel choices and find no measurable differences. These robustness tests are presented in the appendix.
} 
school graduation cohorts took more than one examination and 36 percent received a 3 or higher on more than one examination. The unidimensional RD analytic framework fails to reveal the impact of receiving two or more credit-granting AP exam scores on this paper's outcomes, the effects of which may or may not be additive. To explore the impacts of receiving multiple AP credit-granting scores, we first adopt the analytic framework established by Papay, Murnane, and Willett (2011) in which equation (1) is expanded to include multiple forcing variables, boundaries and interactions as in the two-dimensional example shown by EQ(2). The sum of parameters $\alpha_{1}^{n}, \alpha_{4}^{n}$ and $\alpha_{8}^{n}$ in $\mathrm{EQ}(2)$ below represent the impact of receiving two additional creditgranting scores on tests $J$ and $K$.

$$
\begin{aligned}
& \text { Outcome }_{i j n}=\alpha_{0}^{n}+\alpha_{1}^{n} \text { Boundary }_{i J n}+\alpha_{2}^{n} \text { Dist }_{i J n}+\alpha_{3}^{n} \text { Boundary }_{i J n} \times \text { Dist }_{i J n}+ \\
& +\alpha_{4}^{n} \text { Boundary }_{i K n}+\alpha_{5}^{n} \text { Dist }_{i K n}+\alpha_{6}^{n} \text { Boundary }_{i K n} \times \text { Dist }_{i K n}+\alpha_{7}^{n} \text { Dist }_{i J n} \times \text { Dist }_{i K n}+ \\
& \alpha_{8}^{n} \text { Boundary }_{i J n} \times \text { Boundary }_{i K n}+\alpha_{9}^{n} \text { Boundary }_{i J n} \times \text { Dist }_{i K n}+\alpha_{10}^{n} \text { Boundary }_{i K n} \times \text { Dist }_{i J n}+ \\
& \alpha_{11}^{n} \text { Boundary }_{i K n} \times \text { Dist }_{i J n} \times \text { Dist }_{i K n}+\alpha_{12}^{n} \text { Boundary }_{i J n} \times \text { Dist }_{i J n} \times \text { Dist }_{i K n}+ \\
& \alpha_{13}^{n} \text { Boundary }_{i J n} \times \text { Boundary }_{i K n} \times \text { Dist }_{i J n}+\alpha_{14}^{n} \text { Boundary }_{i J n} \times \text { Boundary }_{i K n} \times \text { Dist }_{i K n}+ \\
& \alpha_{15}^{n} \text { Boundary }_{i J n} \times \text { Boundary }_{i K n} \times \text { Dist }_{i J n} \times \text { Dist }_{i K n}+X_{i j}+\varepsilon_{i j n}
\end{aligned}
$$

Using pairings of the six most commonly taken AP exams in our data set, we fit equation (2) to examine the impact of receiving two additional credit-granting scores on four, five and six year bachelor's degree completion rates.

\subsection{Marginal Analyses}

We conclude our analyses by estimating the impacts of receiving an additional creditgranting AP exam score on bachelor's degree completion. The previously described analytic strategies do not account for the fact that many sampled students will have taken and received credit-granting scores on other AP exams. Equation 1 allows us to estimate the impact of receiving a credit-granting score on AP Biology (for example), not the impact of only receiving a 
credit-granting score in Biology and no other exams. Similarly, Equation 2 allows us to estimate the impact of receiving an additional two credit-granting scores, not the impact of receiving only two credit-granting scores.

It is possible that the first AP credit-granting score confers students with the largest advantages in terms of bachelor's degree completion and each additional credit-granting score yields smaller marginal impacts. To test this, we modify equation (1) so that the forcing variable indicates how close the student was to receiving $X+1$ credit-granting AP exam scores over $X$ credit-granting AP exam scores. For each marginal analysis, we restrict the sample only to those students who received either $X$ or $X+1$ credit-granting AP exam scores. We then re-define the forcing variable as the minimum distance to 0 among all negative subject-specific distances to the credit-granting threshold for students with $X$ credit-granting AP exam scores and the

minimum distance to 0 among all positive subject-specific distances to the credit-granting threshold for students with $X+1$ credit-granting AP exam scores. We continue to control for cohort and subject-by-high school grade fixed effects.

\section{Results}

\subsection{Density and Covariate Balancing Tests}

To validate our regression discontinuity approach, we first verify that there are no discontinuities in the density of student raw scores across each of the four scaled boundaries for the AP subject exams that we study. In these density tests, we collapse observations into one raw score point bins, by cohort and high school year in which exam was taken. Counts are then regressed on distance from threshold, an indicator variable for whether the raw score is above the 
specified threshold, an interaction of these two terms, and dummy variables for high school graduation cohort and examination year.

In most RD settings, this type of density test might be performed to detect the presence of score manipulation. However, since the AP scoring rubric is unpublicized, no students would realistically be able to game the system in this manner. An alternative source of density discontinuity might originate from the placement of score boundaries, by the scorers, at points along the raw score distribution that represent particularly sharp breaks in student ability. The parameter estimates in Table 2 confirm that density is smooth across each of the four scaled thresholds. None are statistically at the 0.05 level.

$<<$ Insert Table 2>>

To test hypothesis (H1), about whether students choose colleges with AP credit policies that favor them (given the AP exam scores they have achieved), we look for a discontinuity in enrollment choices at each threshold in AP exam raw score. Figure 1 presents a histogram of the differences between students' raw AP exam scores and the colleges' qualifying AP exam scores, across all exams taken by on-time four-year college-going students for all AP exams (top panel) and for exams taken during a student's junior year (bottom panel), before which a college decision has been formalized. Visually, no discontinuities exist, suggesting that students are not sorting into colleges based on those colleges' credit/placement policies.

Table 3 presents the results of tests for discontinuities in density of observations and covariate imbalance at the college-policy thresholds for the six most popular AP exams. There exists no clear evidence of discontinuity in the density of observations (Column 1) and the set of covariates presented in this paper are generally well balanced across the thresholds (remaining columns). This provides evidence against hypothesis (H1). That is, students are not choosing 
their colleges based on the favorability of their credit-granting policies in relation to their AP exam scores.

$<<$ Insert Figure 1, Table 3>>

\subsection{AP Exam Scores and Time to Bachelor's Degree}

As a precursor to our analysis of the individual hypotheses (H2) to (H5), we assess the overall effect of an increase in AP exam score, in particular from just below to just above the threshold for college credit. This formulation combines all of the different channels by which an increase in AP exam scores influences the time to completing a BA degree.

Figure 2 presents the parameter estimates and t-statistics for regression discontinuity tests for each of the 34 different AP exams for all students (high school juniors and seniors) and completion of a BA degree within four, five and six years of high school graduation as dependent variables. For each student, we compute the distance in raw score to the threshold required for credit at the college where this student first enrolled after high school graduation. In most cases, we use the distance to the $2 / 3$ scaled score cutoff as the distance to the threshold, but since the credit policies for each exam vary to some degree across colleges, we use different scaled score cutoffs for some students. Here, we rely on the results of our earlier analysis of (H1) to justify the use of this "distance to credit threshold" value as an independent variable in a regression discontinuity specification, since that analysis indicates that students do not appear to change colleges in response to a score just above or below a score threshold (i.e. near a value of 0 for the "Distance to Threshold" measure).

The top left panel of Figure 2 presents t-statistics and the top right panel of Figure 2 presents coefficient estimates for exams with completion of BA degree within four years of high school graduation as the dependent variable. The effect of meeting the college's 
credit/placement guidelines is estimated to be positive in 26 of 34 cases, typically with a magnitude of an increase between one-half and one percentage point in probability of graduation in four years. Since the sample sizes for most exams are quite large, we find that more than half (14 of 26) of the positive coefficients, but none of the negative coefficients on achieving the credit threshold are significant at the 0.05 level. When we restrict analysis to the 19 subjects with more than 100,000 observations, we find that an even larger proportion of exams - 12 out of 19 - yield positive and statistically significant coefficient estimates.

The middle and bottom panels of Figure 2 show the results with BA degree completion within five and six years, respectively, as the dependent variable. These results provide suggestive evidence that both the magnitudes and statistical significance of the parameter estimates fade over time. That is, meeting the threshold for college credit on an AP exam appears to reduce the expected time to completion of a BA degree, but also does not appear to increase the long-run probability of completing a BA degree. This may reflect the difference in baseline four-year and six-year graduation rates. Among students with AP exam scores just below credit-granting thresholds, approximately 60 percent complete BA degrees within four years of high school graduation, whereas more than 80 percent complete BA degrees within six years of high school graduation. Since such a large percentage of these students complete BA degrees within six years of high school graduation, the benefit of an additional AP exam credit may have little influence on the long-run outcomes of those who would not otherwise complete a BA degree within six years.

Tables 4 and 5 present the formal estimates for four- and six-year bachelor's degree completion rates corresponding to the most common exams in Figure $2 .{ }^{17}$ As shown in the right most column of Table 4, the effect of exceeding the credit threshold on four-year graduation is

\footnotetext{
${ }^{17}$ Five-year graduation rates are presented in Appendix Table 3.
} 
statistically significant at the .05 level for five of these six AP exams. By contrast, as shown in the right most column of Table 5, the effect of exceeding the credit threshold on six-year graduation is only statistically significant at the .05 level for two of these six exams. Further, on an exam-by-exam basis, the magnitudes of the coefficient estimates are smaller for six-year graduation than for four-year graduation.

Columns 1 and 4 of Tables 4 and 5 repeat these analyses for all students with raw scores near the cutoff for scaled scores of 2 versus 3 and separately near the cutoff for scaled scores of 3 versus $4 .{ }^{18}$ These coefficient estimates, especially those in Column 1 (for the $2 / 3$ scaled score cutoff) are broadly similar to the estimates for the "Distance to Cutoff" specification in Column 7 of Tables 4 and 5, suggesting that receiving higher AP exam scores improves time-to-degree. $<<$ Insert Tables 4,5>>

To distinguish hypotheses (H2) and (H3), which consider the direct effect of credit receipt versus the psychological boost of a higher AP exam score, we compute separate analyses at each scaled score threshold for (A) students attending colleges that use this threshold as the minimum for college credit and (B) students attending colleges that do not use this threshold as the minimum for college credit. As shown in Columns 2-3 and 5-6 of Table 4, we estimate that receiving an AP exam score of a 3 over a 2 results in a statistically significant increase in the probability of four-year bachelor's degree completion of 1 to 2 percentage points, but only when that score of 3 is high enough for the student to earn credit. Similarly, we find that achieving a score of 4 over a 3 enhances the student's probability of completing a bachelor's degree in four years only when 4 is the minimum credit-granting score. ${ }^{19}$

\footnotetext{
${ }^{18}$ Only students who enroll in four-year colleges as first-time on-time students are included in these analyses.

${ }^{19}$ The obvious exception to this pattern is AP Biology, for which exceeding a certain AP threshold contributes to an improved bachelor's degree completion probability only when the threshold does not translate into a difference in whether the student is eligible for college credit. It is not possible to explain this bewildering finding with the
} 
To refine this assessment, we restrict the sample to high school seniors taking AP exams and repeat these same specifications for four of the six popular exams studied in Table 4, excluding English Composition and U.S. History, which are relatively rarely taken by high school seniors. We note that high school seniors have already selected a college by the time that they receive their scores, so should not be subject to the effects described in hypotheses (H1), (H4) and (H5), which consider college choice.

Table 6 shows that we find positive and statistically significant effects (at the .10 level) for three of the four subjects at the $2 / 3$ scaled score cutoff and also at the $3 / 4$ scaled score cutoff for students attending colleges that use these separate cutoffs at the thresholds for college credit. By contrast, we only find one statistically significant coefficient among the eight exams (four exams at the $2 / 3$ scaled score cutoff and four more exams at the $3 / 4$ scaled score cutoff) for gains in exam scores that do not correspond to a course credit threshold at the colleges where the students enrolled. Taken together, these results weigh in favor of the direct effect of college credit receipt in hypothesis $(\mathrm{H} 2)$ over the psychological boosts associated with relatively higher AP exam score in hypothesis (H3).

$<<$ Insert Table 6>>

\subsection{Impacts on Subsequent AP Exam Taking for High School Juniors}

To test whether early success on AP exams encourages more advanced course work and success, hypothesis (H4), we perform regression discontinuity tests for junior year exam-takers using dependent variables based on senior year AP exam taking and scores. Since most AP exam-takers will not have selected a college in their junior year, we use the same threshold either the $2 / 3$ or $3 / 4$ scaled score cutoff - regardless of the credit policies at the first college 
where each student enrolled after high school graduation. Figure 3 graphs the average number of senior year AP exams taken and the average number of scores of 3 or higher in senior year exams by distance from the $2 / 3$ threshold on each junior year exam. ${ }^{20} \mathrm{We}$ find discontinuities on the order of about 0.10 senior year exams taken and 0.05 exams passed are present for all subjects except for Calculus $\mathrm{AB}$. But students who take the Calculus $\mathrm{AB}$ exam as juniors are probably unusually accelerated, even within the population of those taking at least one AP exam as a high school junior, and may have received sufficient academic affirmation in prior courses that an additional signal of academic aptitude (in the form of an AP exam score) has little effect on them.

Table 7 presents numerical estimates of the marginal effect of an increase scaled junior year AP exam score on each of the six most popular AP exams on senior year AP exam taking and performance. Consistent with the results of Figure 3, we find that an increase in scaled score from 2 to 3 increases the number of AP exams taken in the senior year; these predicted increases are statistically significant at the 5\% level for five of the six exams and at the $10 \%$ level for the remaining exam, Calculus AB. Across the other boundaries, there exist some positive, statistically significant increases in senior year AP exam taking. These provide suggestive evidence that even receiving a signal that a student is "possibly qualified" (AP exam score=2) rather than "no recommendation" (AP exam score=1) induces an increase in senior year AP exam taking.

\section{$<<$ Figure 3, Insert Table 7>>}

These results provide support for hypothesis (H4). Yet, a back of the envelope calculation suggests that while success on an AP exam as a high school junior is predicted to induce additional AP exam participation as a high school senior, this additional exam taking as a

\footnotetext{
${ }^{20}$ We cannot observe AP course taking, only exam taking.
} 
senior is likely to have only a second-order effect on post-secondary success. For example, Table 7 suggests that an increase in scaled score from 2 to 3 increases the number of scores of 3 or higher on senior year exams by at most 0.09 . But since the estimates from Tables 4 and 6 suggest that each additional score of 3 or higher as a high school senior increases the probability of on-time completion of a BA degree by about 1 to 2 percentage points, an increase of 0.09 AP credit-granting scores would translate into an extremely small effect on time to completion of a BA degree.

\subsection{Score-Sending and College Choice}

To test hypotheses (H5a) and (H5b), which consider college application and admission, we first assess the effects of achieving certain AP exam scores on the student's college search process and whether or not the student enrolls at a four-year college on-time. We rely on the number of SAT Score Sends as a proxy for number of applications. A discontinuity in this metric would strongly suggest that achieving certain AP exam scores alters the number of college applications submitted. Since high school seniors send SAT scores to colleges before they take AP exams, estimates for exams taken senior year serve as placebo tests for junior year estimates.

The first six columns of Table 8 show that achieving a score of 3 over 2 or a score of 4 over 3 on AP exams taken during a student's junior year of high school tend not to impact SAT score sending. Among the 12 parameter estimates presented for junior year SAT test takers, only one (English Language and Composition at the $2 / 3$ boundary) is statistically significant. The magnitude of this parameter estimate indicates that receiving a score of 3 on AP English Language and Composition causes the student to send 0.10 (2.5 percent) more scores to colleges. As expected, almost all (11 out of 12) placebo tests using SAT score sends of high school senior AP exam-takers are statistically indistinguishable from zero. In Appendix Table 8, we show little 
heterogeneity along the lines of parental income in shifting college application behavior as a result of achieving scores of 3 or 4 .

In the last six columns of Table 8 , we present regression discontinuity parameter estimate of the average SAT scores of colleges selected by first-time on-time four-year college enrollees. Restricting analyses to AP exam scores on the six most popular AP exams for high school juniors, we find only one statistically significant (positive) effect at the $2 / 3$ scaled score cutoff and one statistically significant (positive) effect at the $3 / 4$ scaled score cutoff. Similarly, in unreported analysis, we find essentially no effect of AP exam scores on enrollment in four-year colleges. This is most likely because the baseline four-year college-going rates among students participating in AP exams is already quite high.

Overall, these results do not support hypotheses $(\mathrm{H} 5 \mathrm{a})$ or $(\mathrm{H} 5 \mathrm{~b})$ in that there are no measurable changes in students' Score Sends or attending college after achieving a relatively high AP exam score.

\section{$<<$ Insert Table $8>>$}

\subsection{Multidimensional RD Impacts}

In Figure 4, we show the distribution of point estimates associated with achieving creditgranting scores on the 15 pairings of the six commonly taken AP exams. These pairings include

all possible two-exam combinations of the six AP exams in Tables 4 and 5 . The pattern is clear. When the outcome of interest is bachelor's degree completion in four years (Panels A and B), the parameter estimates are mostly positive. In fact, at a bandwidth of 20 , only one of the 15 multidimensional parameter estimates in Panel B is negative, and the magnitude of this one parameter estimate is only $-0.4 \mathrm{pp}$. Expanding the time to bachelor's degree completion from 
four years to six years results in a more equally distributed number of positive and negative parameter estimates (Panels E and F).

On average, the magnitudes of the four-year bachelor's completion parameter estimates in Panels A and B are about twice as large as the unidimensional point estimates presented in Table 4. When observations are restricted only to those within 10 raw points of the creditgranting boundary, the average impact of receiving an additional two credit-granting scores across all 15 pairings is 3.2 percentage points. When the bandwidth is expanded to $+/-20$ raw points, the average impact on four-year bachelor's completion is 2.7 percentage points.

\section{$<<$ Insert Figure 4>>}

Despite the fact that, in the unidimensional RD framework, we were unable to detect a boost in four-year bachelor's degree completion from receiving a credit-granting score in AP Biology, our analysis in the multidimensional $\mathrm{RD}$ framework suggests that when paired with other AP examinations, success on AP Biology substantially increases four-year bachelor's completion rates. In fact, some of the largest estimates shown in the histogram Figure 4 (panels $\mathrm{A}$ and B) are for AP Biology pairings. When the bandwidth is $+/-10$ raw points, receiving/ a credit-granting score on AP Biology and AP US Government, AP Biology and AP English Language and Composition and AP Biology and AP US History increases the probability of receiving a bachelor's degree in four years by $9.4 \mathrm{pp}, 8.0 \mathrm{pp}$ and $5.0 \mathrm{pp}$ respectively. The corresponding percentages when the bandwidth is expanded to $+/-20$ raw points are $2.5 \mathrm{pp}, 5.1$ pp and $4.0 \mathrm{pp}$. Also notable is the pairing of Calculus $\mathrm{AB}$ and English Language and Composition, credit eligibility on both of which leads to the largest point estimates on four-year bachelor's degree completion for both bandwidths among all 15 pairings (10.1 pp at a bandwidth of $+/-10$ raw points and $5.4 \mathrm{pp}$ at a bandwidth of $+/-20$ raw points). 


\subsection{Marginal Impacts}

In this section of results, we address whether the impact of receiving an additional creditgranting AP exam score on bachelor's degree completion and time to completion depends on the number of credit-granting scores that the student had already amassed. These analyses differ from all previous analyses in that we do not discern between the 34 AP subjects for which we have college-specific AP credit-granting score minima. Table 9 shows the impact of bachelor's degree completion probability driven by each incremental increase in the number of creditgranting AP exam scores earned. Students who have met the credit-granting threshold on just one AP exam are 1.2 percentage points more likely to have earned a bachelor's degree within four years than students who just missed earning a credit-granting AP exam score. Transitioning from one credit-granting AP exam score to two results in an additional 0.8 percentage point boost in four-year bachelor's degree completion. Progression from four to five credit-granting AP exam scores yields increases in four-year and six-year bachelor's degree completion probabilities of 1.2 and 0.9 percentage points, respectively.

\section{$<<$ Insert Table 9>>}

Parameter estimates in Table 9 can be used to draw inferences about the cumulative impacts of achieving credit-granting scores on AP exams. For example, the parameter estimates in Column 1 suggest that students who earn credit-granting scores on two AP exams could experience a 2.0 percentage point bump in four-year bachelor's degree completion probability attributable to those credit-granting scores. This 2.0 percentage point bump is calculated as the sum of the first two parameter estimates (1.2 and 0.8 percentage points) in Column 1 and is roughly equal to the multidimensional estimates on the passing of two AP exams presented in Section 5.5. The consistently positive, though imprecisely estimated, parameter estimates in 
Column 1 reveal that the marginal benefits of earning additional credit-granting AP exam scores continues to increase four-year bachelor's degree completion rates beyond the first two passing scores. Addition of the first five parameter estimates in Column 1 suggests that one college semester's worth of AP credits may increase four-year bachelor's degree completion rates by nearly 4 percentage points.

\subsection{Heterogeneous Effects}

We hypothesized that the effects of AP exam scores on college choices and college completion might be unusually pronounced for students from low-income families. To test this hypothesis, we repeat the analysis from Tables 4 and 5 for subgroups of students based on selfreported family income. The results, as shown in Table 10, are consistent with the earlier findings, which suggest that AP credit-granting policies have an effect on four-year bachelor's degree completion rates, but much less, if any effect, upon six-year bachelor degree completion rates. However, we see no obvious patterns across family income in RD estimates for four-year and six-year completion of bachelor's degrees. Since our measure of family income is based on student self-report, which is likely to be fairly noisy, we do not regard the coefficients in Table 10 as precise estimates of heterogeneous effects as a function of family income. Nevertheless, if the effects of AP credit policies are concentrated in students from families with relatively low incomes, we would still expect to see conspicuous patterns by income in Table 10. Since this is not the case, we tentatively rule out the hypothesis that AP credit is unusually important for students from low-income families.

$<<$ Insert Table 10>>

We also test for heterogeneous effects by race and parental income and also find no obvious differences. Results are reported in Appendix 7. 


\section{Discussion and Conclusion}

In this study, we find evidence that attaining a relatively high AP exam score yields a significant increase in the probability of completing a bachelor's degree within four years of high school graduation. For high school seniors, we attribute most of this effect to the direct effect of an AP credit towards college graduation requirements (empirical hypothesis (H2)), since we find little to no effect on bachelor's degree completion from an increase in AP exam scores for high school seniors when those increases in scores are not at the credit/no-credit boundary at the college attended by that student. Thus we rule out empirical hypothesis (H3), which suggests that a marginal increase in AP exam score improves post-secondary outcomes by providing a psychological boost to students.

We also find evidence that earning scores of 3 or higher on AP exams for high school juniors induces increased participation and success on AP exams (empirical hypothesis (H4)) in the senior year of high school. However, this increase is still of relatively small magnitude - e.g. an improvement in AP exam score from 2 to 3 or 3 to 4 predicts an increase of approximately 0.1 additional AP exams taken as a high school senior - and is only predicted to produce secondorder effects on time to bachelor's degree completion. While students with higher AP exam scores tend to enroll in more selective four-year colleges, we find little causal evidence that the AP exam scores themselves radically shift whether or not a student enrolls at a four-year college or the type of college chosen, as measured by average college-level SAT scores (empirical hypothesis (H1) and (H5)). In particular, it does not appear that an increase in AP exam score for a high school junior alters the colleges to which she sends SAT scores. Given this pattern of results, we also attribute the significant increase in the probability of completing a bachelor's degree within four years of high school graduation that we observe for high school juniors to the 
direct effect of an AP credit towards college graduation requirements (empirical hypothesis (H2)).

One unique result that we did not previously highlight is that our estimates on the effect of credit on four-year graduation rates are similar on the $2 / 3$ boundary and the $3 / 4$ boundary. Typically in a regression discontinuity design, researchers have one discontinuity to exploit and the estimated treatment effect is localized. In this analysis, there is evidence that the treatment effect is constant, at least on the 3 to 4 range.

We believe that these findings have positive implications for colleges and students. From the perspective of postsecondary institutions, awarding AP credit and/or placement may serve as a useful tool for increasing the percentage of students who complete bachelor's degrees in four years. By awarding college credit and advanced placement to successful AP examinees, postsecondary institutions can free students from unnecessary curricular repetition while simultaneously responding to the issues of overcrowding of introductory courses in the nation's larger university systems (Moltz, 2009; Murphy, 2013). ${ }^{21}$

For students, AP exams can reduce the total costs associated with a postsecondary education. During the 2013-2014 academic year, the typical student attending a four-year public college faced tuition and fees of $\$ 8,893$ (Baum and Ma, 2013). Assuming that a typical student completes 30 credits per year, savings from earning credit on one AP exam has the potential to save that student an estimated $\$ 889$ in costs for colleges that charge tuition per credit. ${ }^{22}$ Further, our finding that each AP course credit increases the probability of completing a bachelor's degree on-time in four years from high school graduation translates into additional expected

\footnotetext{
${ }^{21}$ Evans (2013) explores this question using a selection on observables identification strategy.

${ }^{22}$ We assume that the student is awarded 3 credits for a passing score and pricing is linear with respect to credits. Depending on the AP exam and the institution, the student might actually receive more than 3 credits for a passing score, meaning that the $\$ 889$ figure probably represents an underestimate.
} 
financial benefits due to (1) reduced tuition costs at colleges that charge by semester rather than by credit and (2) increased wages and career benefits due to potential earlier entry into the labor market.

A final and important note is that the estimates in this paper represent a lower-bound on the total effects of the AP program. Some students with the potential to benefit from sharing AP exam results with their chosen colleges may have instead withheld these scores or colleges may have additional restrictions on the credit policies (e.g. maximum number of AP credits). This behavior would understate our estimated effects on bachelor's degree completion. Similarly, we are unable to offer any commentary on the cumulative effects of taking an AP course and earning credit on the associated AP exam. Because our estimation strategy relies on the comparison of two sets of students- those who barely achieved a credit-granting score and those who barely missed a credit-granting score-, we are unable to determine how the content of the AP course influences bachelor's degree completion, which is necessary to fully determine the costs and benefits of the AP program.

\section{References}

Baum, S. and J. Ma (2013). “Trends in College Pricing,” The College Board.

Bound, J., M. Lovenheim and S. Turner (2010). "Why Have College Completion Rates Declined? An Analysis of Changing Student Preparation and Collegiate Resources," American Economic Journal: Applied Economics. 2(3): 129-157.

Bound, J., M. Lovenheim and S. Turner (2012). "Increasing Time to Baccalaureate Degree in the United States," Education Finance and Policy. 7(4): 375-424.

Chajewski, M., Mattern, K., and Shaw, E. J. (2011). "AP participation and college enrollment" Education Measurement: Issues and Practice, 30, 16-27.

College Board (2013a). “Trends in Student Aid 2013,” Trends in Higher Education Series. 
College Board (2013b). "Program Summary Report," available online:

http://media.collegeboard.com/digitalServices/pdf/research/2013/Program-Summary-Report2013.pdf

Conger, D., M. Long, and R. McGhee (2014). "Evaluation of the Sustainability and Effectiveness of Inquiry-Based Advanced Placement Science Courses: Evidence from an InDepth Formative Evaluation \& Randomized Controlled Study." IES Grant.

Dougherty, C., Mellor, L., and Jian, S. (2008). "The Relationship between Advanced Placement and College Graduation," Education, 501(February 2006), 1-35.

Evans B. (2013). "How do College Students use Advanced Placement Credit?" Working paper.

Hargrove, L., Godin, D., and Dodd, B. (2008). "College Outcomes Comparisons by AP and Non-AP High School Experiences.” Higher Education. (Research Rep. No. 2008-3). New York, NY: The College Board.

Hoxby, C. and C. Avery, (2013). The Missing "One-Offs": The Hidden Supply of HighAchieving, Low-Income Students," Brookings Papers on Economic Activity, Spring 2013.

Imbens, G.W and K. Kalyanaram (2012). "Optimal Bandwidth Choice for the Regression Discontinuity Estimator.” Review of Economic Studies. 142 (2): 615-635.

Jackson, K. (2010). “A Little Now for A lot Later: An Evaluation of a Texas Advanced Placement Incentive Program.” Journal of Human Resources. 45(3):591-639.

Johnson, N., Reidy, L., Droll, M. and LeMon, R.E. (2012). "Program Requirements for Associate's and Bachelor's Degrees: A National Survey." Retrieved from http://completecollege.org/docs/Program\%20Requirements\%20$\% 20 \mathrm{~A} \% 20$ National $\% 20$ Survey.pdf

Karp, M. M., Calcagno, J. C., Hughes, K. L., Jeong, D. W., and Bailey, T. (2007). “The postsecondary achievement of participants in dual enrollment: An analysis of student outcomes in two states." St. Paul: University of Minnesota, National Research Center for Career and Technical Education.

Lacy, T. (2010). "Examining AP: Access, Rigor and Revenue in the History of the Advanced Placement Program," in AP: A Critical Examination of the Advanced Placement Program, ed. Sadler, P.M., G. Sonnert, R.H. Tai and K. Klopfenstein (Cambridge: Harvard University Press).

Long, M. C., Conger, D., and Iatarola, P. (2012). "Effects of high school course-taking on secondary and postsecondary success." American Educational Research Journal. 49(2), 285322. 
Mattern, K.D., Marini, J.P., Shaw, E.J. (2013). “Are AP Students More Likely to Graduate from College on Time," (College Board Research Report 2013-5). New York: The College Board.

McCrary, J.(2008). "Manipulation of the Running Variable in the Regression Discontinuity Design: A Density Test," Journal of Econometrics. 142(2): 698-714.

Moltz, D. (2009). "No Vacancy," Inside Higher Ed. Retrieved from http://www.insidehighered.com/news/2009/07/21/california

Morgan, R., and Klaric, J. (2007). "AP Students in College : An Analysis of Five-Year Academic Careers," (College Board Research Report 2007-4). New York: The College Board.

Murphy, D. and Dodd, B. G. (2009). “A Comparison of College Performance of Matched AP and Non-AP Student Groups," (College Board Research Report No. 2009-6). New York: The College Board.

Murphy, K. (2013). “California State University Unveils 'Radical' New Plan for Online Courses," Oakland Tribune.

Pallais, A. (2013). "Small Differences that Matter: Mistakes in Applying to College . Forthcoming, Journal of Labor Economics. 2013.

Patterson, B. F., and Ewing, M. (2013). "Validating the Use of AP Exam Scores for College Course Placement," (Research Rep. No. 2013-2). New York, NY: The College Board.

Papay, J.P., Willett, J.B. and Murnane, R.J. (2011). "Extending the Regression Discontinuity Approach to Multiple Assignment Variables," Journal of Econometrics. 161: 203-207.

Schochet, P., Cook, T., Deke, J., Imbens, G., Lockwood, J.R., Porter, J., Smith, J. (2010). Standards for Regression Discontinuity Designs. Retrieved from What Works Clearinghouse website: http://ies.ed.gov/ncee/wwc/pdf/wwc_rd.pdf.

Shaw, E. J., Mattern, K. D., and Marini, J. P. (2012). "Exploring the Utility of Advanced Placement Participation and Performance in College Admission Decisions," Educational and Psychological Measurement.

Theokas, C. and R. Saaris. (2013). "Finding America's Missing AP and IB Students," Ed Trust, Retrieved from http://www.edtrust.org/sites/edtrust.org/files/Missing_Students.pdf 


\begin{tabular}{|c|c|c|c|c|}
\hline AP Exam Takers & Biology & Calculus AB & English Lang \& Comp & US History \\
\hline
\end{tabular}

(1000s) Mean Dev (1000s) Mean Dev (1000s) Mean Dev (1000s) Mean Dev (1000s) Mean Dev (1000s) Mean Dev (1000s) Mean Dev

\begin{tabular}{|c|c|c|c|c|c|c|c|c|c|c|c|c|c|c|c|c|c|c|c|c|c|}
\hline & 00 & Mean & Dev & $000 s)$ & Mea & Dev & 1000 & Mean & Dev & 100 & $\mathrm{Me}$ & Del & 0 & $\mathrm{Me}$ & Del & 1000 & Mean & Dev & 10 & vet & Dev \\
\hline \multicolumn{22}{|l|}{ (A) Demographics } \\
\hline Male & 528 & 0.44 & 0.50 & 691 & 0.41 & 0.49 & 1,120 & 0.51 & 0.50 & 1,229 & 0.37 & 0.48 & 1,641 & 0.36 & 0.48 & 847 & 0.47 & 0.50 & 1,438 & 0.45 & 0.50 \\
\hline White & 528 & 0.64 & 0.48 & 691 & 0.63 & 0.48 & 1,120 & 0.67 & 0.47 & 1,229 & 0.64 & 0.48 & 1,641 & 0.67 & 0.47 & 847 & 0.64 & 0.48 & 1,438 & 0.67 & 0.47 \\
\hline Black & 4,528 & 0.07 & 0.26 & 691 & 0.06 & 0.24 & 1,120 & 0.05 & 0.21 & 1,229 & 0.07 & 0.26 & 1,641 & 0.07 & 0.26 & 847 & 0.06 & 0.24 & 1,438 & 0.06 & 0.24 \\
\hline Hispan & 4,528 & 0.13 & 0.34 & 691 & 0.08 & 0.28 & 1,120 & 0.09 & 0.28 & 1,229 & 0.13 & 0.33 & 1,641 & 0.11 & 0.31 & 847 & 0.12 & 0.33 & 1,438 & 0.11 & 0.31 \\
\hline Asian & 4,528 & 0.11 & 0.31 & 691 & 0.18 & 0.39 & 1,120 & 0.16 & 0.36 & 1,229 & 0.11 & 0.32 & 1,641 & 0.10 & 0.31 & 847 & 0.13 & 0.33 & 1,438 & 0.12 & 0.32 \\
\hline Parent & 4,528 & 0.08 & 0.28 & 691 & 0.07 & 0.26 & 1,120 & 0.08 & 0.27 & 1,229 & 0.08 & 0.28 & 1,641 & 0.08 & 0.27 & 847 & 0.08 & 0.28 & 1,438 & 0.08 & 0.27 \\
\hline Paren & 4,528 & 0.14 & 0.34 & 691 & 0.13 & 0.34 & 1,120 & 0.13 & 0.33 & 1,229 & 0.14 & 0.35 & 1,641 & 0.14 & 0.34 & 847 & 0.14 & 0.35 & 1,438 & 0.14 & 0.35 \\
\hline Pare & 4,528 & 0.43 & 0.50 & 691 & 0.50 & 0.50 & 1,120 & 0.49 & 0.50 & 1,229 & 0.49 & 0.50 & 1,641 & 0.48 & 0.50 & 847 & 0.52 & 0.50 & 1,438 & 0.51 & 0.50 \\
\hline Low & 4,528 & 0.14 & 0.35 & 691 & 0.13 & 0.34 & 1,120 & 0.13 & 0.34 & 1,229 & 0.15 & 0.35 & 1,641 & 0.14 & 0.35 & 847 & 0.15 & 0.35 & 1,438 & 0.14 & 0.34 \\
\hline & ,528 & 0.17 & 0.38 & 691 & 0.18 & 0.39 & 1,120 & 0.19 & 0.39 & 1,229 & 0.19 & 0.40 & 1,641 & 0.19 & 0.39 & 847 & 0.19 & 0.40 & 1,438 & 0.19 & 0.39 \\
\hline High & 4,528 & 0.15 & 0.36 & 691 & 0.18 & 0.38 & 1,120 & 0.17 & 0.38 & 1,229 & 0.18 & 0.38 & 1,641 & 0.17 & 0.37 & 847 & 0.19 & 0.39 & 1,438 & 0.18 & 0.39 \\
\hline \multicolumn{22}{|l|}{ (B) Tes } \\
\hline $\operatorname{Rec}$ & 4,528 & 0.48 & 0.82 & 691 & 0.21 & 0.41 & 1,120 & 0.25 & 0.43 & 1,229 & 0.11 & 0.31 & 1,641 & 0.09 & 0.28 & 847 & 0.18 & 0.38 & 1,438 & 0.22 & 0.41 \\
\hline $\operatorname{Rec}$ & 4,528 & 0.59 & 0.83 & 691 & 0.21 & 0.41 & 1,120 & 0.16 & 0.37 & 1,229 & 0.32 & 0.47 & 1,641 & 0.30 & 0.46 & 847 & 0.29 & 0.46 & 1,438 & 0.26 & 0.44 \\
\hline Recei & 4,528 & 0.67 & 0.95 & 691 & 0.20 & 0.40 & 1,120 & 0.19 & 0.39 & 1,229 & 0.32 & 0.47 & 1,641 & 0.33 & 0.47 & 847 & 0.27 & 0.44 & 1,438 & 0.22 & 0.42 \\
\hline Rece & 4,528 & 0.53 & 0.96 & 691 & 0.19 & 0.39 & 1,120 & 0.20 & 0.40 & 1,229 & 0.18 & 0.38 & 1,641 & 0.21 & 0.41 & 847 & 0.17 & 0.38 & 1,438 & 0.20 & 0.40 \\
\hline Received AP Score $=5$ & 4,528 & 0.37 & 1.02 & 691 & 0.18 & 0.39 & 1,120 & 0.21 & 0.41 & 1,229 & 0.08 & 0.28 & 1,641 & 0.07 & 0.26 & 847 & 0.09 & 0.28 & 1,438 & 0.10 & 0.30 \\
\hline \multicolumn{22}{|l|}{ (C) College outcomes } \\
\hline Atte & 4,528 & 0.84 & 0.37 & 691 & 0.9 & 0. & 1,120 & 0.91 & 0.29 & 1,229 & 0.88 & 0.33 & 1,641 & 0.89 & 0. & 847 & 0.90 & 0.30 & 1,438 & 0.89 & 0.31 \\
\hline Atter & 4,528 & 0.77 & 0.42 & 691 & 0.85 & 0.3 & 1,120 & 0.86 & 0.34 & 1,229 & 0.81 & 0.39 & 1,641 & 0.84 & 0.3 & 847 & 0.84 & 0.37 & 1,438 & 0.83 & 0.38 \\
\hline Mear & 3,328 & 1,157 & 126 & 572 & 1194 & 133 & 940 & 1192 & 124 & 966 & 1173 & 130 & 1,330 & 1177 & 130 & 695 & 1181 & 125 & 1,155 & 1181 & 131 \\
\hline Bache & 4,528 & 0.41 & 0.49 & 691 & 0.52 & 0.50 & 1,120 & 0.50 & 0.50 & 1,229 & 0.47 & 0.50 & 1,641 & 0.49 & 0.50 & 847 & 0.50 & 0.50 & 1,438 & 0.49 & 0.50 \\
\hline Bachelors in Five Years & 3,604 & 0.57 & 0.49 & 545 & 0.68 & 0.47 & 907 & 0.68 & 0.47 & 938 & 0.63 & 0.48 & 1,327 & 0.65 & 0.48 & 671 & 0.66 & 0.47 & 1,112 & 0.65 & 0.48 \\
\hline $\mathrm{Bac}$ & 2,721 & 0.63 & 0.48 & 404 & 0.72 & 0.45 & 698 & 0.73 & 0.45 & 671 & 0.68 & 0.47 & 1,021 & 0.70 & 0.46 & 502 & 0.71 & 0.45 & 802 & 0.70 & 0.46 \\
\hline
\end{tabular}

Notes: The unit of observation is a student. Means and standard deviations are calculated using the raw AP scores. Because raw AP score data were unavailable before 2004, some sampled

students, particularly for earlier high school graduation cohorts, will have participated in more AP exams than their raw scores would suggest. 
Table 2: Density Tests at the Integer Thresholds

\begin{tabular}{|c|c|c|c|c|}
\hline & $1 / 2$ & $2 / 3$ & $3 / 4$ & $4 / 5$ \\
\hline \multicolumn{5}{|l|}{ (A) Biology (BW=32.164) } \\
\hline Above threshold & $\begin{array}{l}11.035 \\
(11.452)\end{array}$ & $\begin{array}{c}1.594 \\
(7.014)\end{array}$ & $\begin{array}{l}-10.560 \\
(7.717)\end{array}$ & $\begin{array}{l}-0.959 \\
(6.448)\end{array}$ \\
\hline Mean below threshold & 357.000 & 451.167 & 444.333 & 328.833 \\
\hline $\mathrm{N}$ & 946 & 693 & 644 & 905 \\
\hline \multicolumn{5}{|l|}{ (B) Calculcus AB (BW=15.844) } \\
\hline Above threshold & $\begin{array}{c}19.102 \\
(27.473)\end{array}$ & $\begin{array}{c}-4.048 \\
(27.408)\end{array}$ & $\begin{array}{l}-0.115 \\
(18.193)\end{array}$ & $\begin{array}{c}-3.387 \\
(14.364)\end{array}$ \\
\hline Mean below threshold & 871.600 & 928.000 & 945.063 & 720.722 \\
\hline $\mathrm{N}$ & 453 & 439 & 492 & 548 \\
\hline \multicolumn{5}{|l|}{ (C) English Language and } \\
\hline \multicolumn{5}{|l|}{ Composition (BW=26.038) } \\
\hline Above threshold & $\begin{array}{c}31.841 \\
(32.598)\end{array}$ & $\begin{array}{c}15.184 \\
(55.520)\end{array}$ & $\begin{array}{l}-54.706 \\
(65.032)\end{array}$ & $\begin{array}{l}-65.623 \\
(62.940)\end{array}$ \\
\hline Mean below threshold & 497.438 & 1144.667 & 1122.250 & 599.933 \\
\hline $\mathrm{N}$ & 831 & 760 & 592 & 657 \\
\hline \multicolumn{5}{|l|}{ (D) English Literature (BW=17.631) } \\
\hline Above threshold & $\begin{array}{l}-14.147 \\
(44.152)\end{array}$ & $\begin{array}{c}103.702 \\
(109.695)\end{array}$ & $\begin{array}{c}-61.633 \\
(118.552)\end{array}$ & $\begin{array}{c}0.758 \\
(113.241)\end{array}$ \\
\hline Mean below threshold & 546.063 & 1457.500 & 1786.733 & 817.067 \\
\hline $\mathrm{N}$ & 544 & 555 & 545 & 508 \\
\hline \multicolumn{5}{|l|}{ (E) US Government (BW=26.225) } \\
\hline Above threshold & $\begin{array}{c}12.333 \\
(16.785)\end{array}$ & $\begin{array}{c}-1.138 \\
(14.563)\end{array}$ & $\begin{array}{l}-12.610 \\
(23.024)\end{array}$ & $\begin{array}{l}-61.168^{*} \\
(34.259)\end{array}$ \\
\hline $\begin{array}{l}\text { Mean below threshold } \\
\mathrm{N}\end{array}$ & $\begin{array}{c}425.056 \\
889\end{array}$ & $\begin{array}{c}694.333 \\
769\end{array}$ & $\begin{array}{l}699.444 \\
596\end{array}$ & $\begin{array}{c}588.545 \\
697\end{array}$ \\
\hline \multicolumn{5}{|l|}{ (F) US History (BW=33.363) } \\
\hline Above threshold & $\begin{array}{c}28.753 \\
(30.066)\end{array}$ & $\begin{array}{c}-6.949 \\
(25.684)\end{array}$ & $\begin{array}{c}-6.435 \\
(24.619)\end{array}$ & $\begin{array}{l}-31.386 \\
(23.976)\end{array}$ \\
\hline $\begin{array}{l}\text { Mean below threshold } \\
\mathrm{N}\end{array}$ & $\begin{array}{c}747.000 \\
956 \\
\end{array}$ & $\begin{array}{c}1045.000 \\
723 \\
\end{array}$ & $\begin{array}{c}896.444 \\
713 \\
\end{array}$ & $\begin{array}{c}551.647 \\
929\end{array}$ \\
\hline \multicolumn{5}{|c|}{$\begin{array}{l}\text { Notes: Heteroskedasticity robust standard errors in parentheses }\left({ }^{*} p<.10,{ }^{* *} p<.05,{ }^{* * *}\right. \\
\mathrm{p}<.01) \text {. All regressions use triangular kernels with fixed effects for cohort and high } \\
\text { school year in which exam was taken. In these density tests, observations are } \\
\text { collapsed into } 1 \text { raw score point bins, by cohort and high school year in which exam } \\
\text { was taken. These counts are then regressed on distance from threshold, an indicator } \\
\text { variable for whether the raw score is above the specified threshold, an interaction of } \\
\text { these two terms, and dummy variables for high school graduation cohort and } \\
\text { examination year. The means below the thresholds represent the mean number of } \\
\text { observations within the high school cohort by exam year categories within } 1 \text { raw } \\
\text { score point bel ow the specified threshold. Optimal bandwidths are selected using the } \\
\text { outcome, bachelor's degree within four years. }\end{array}$} \\
\hline
\end{tabular}


Table 3: Density and Covariate Balance Tests at the College Credit Policy Boundaries

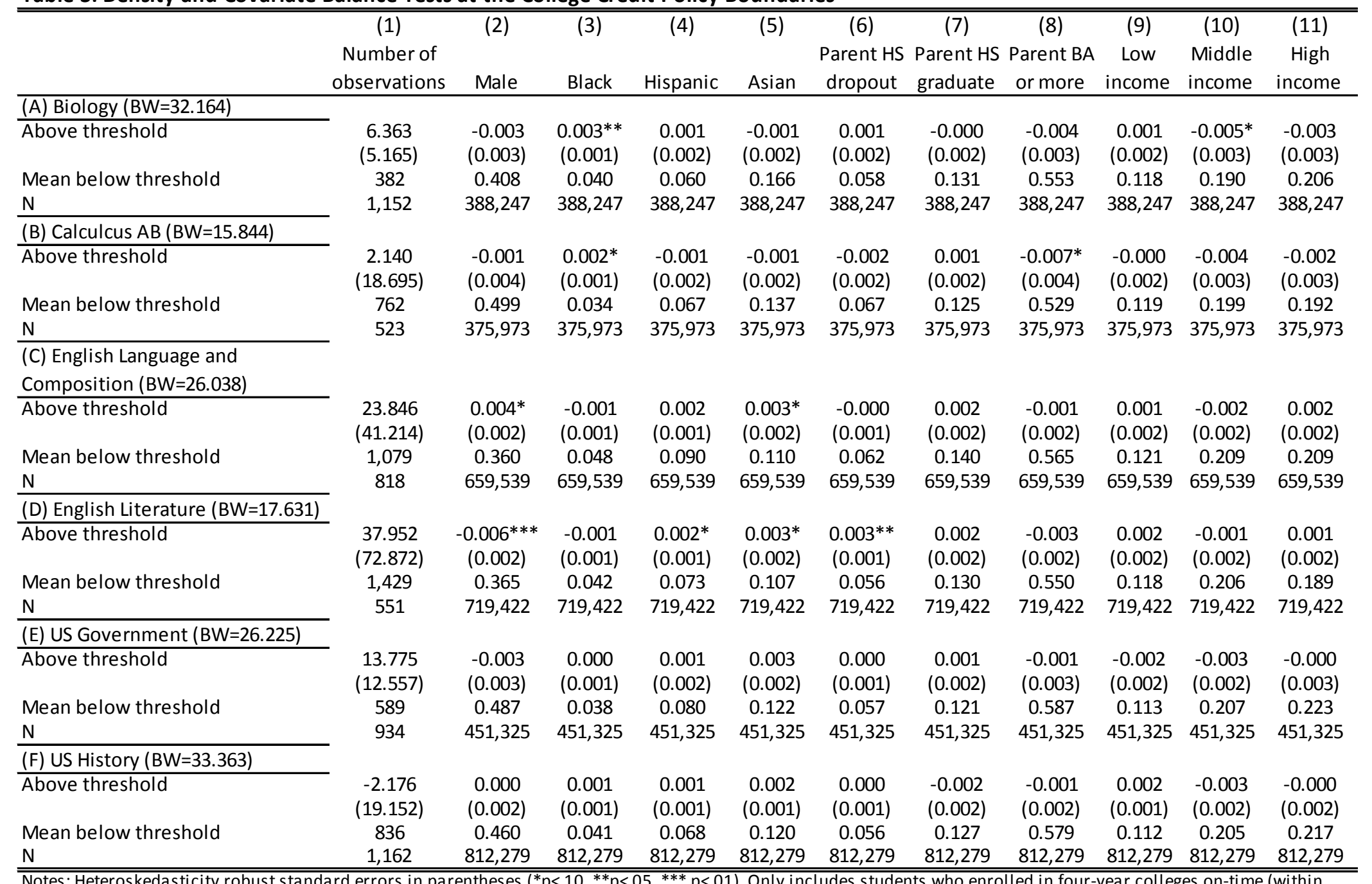

180 days of HS graduation). All regressions use triangular kernels with fixed effects for cohort and high school year in which exam was taken. In the density tests

peformed in Column 1, observations are collapsed into 1 raw score point bins, by cohort and high school year in which exam was taken. These counts are then regressed on distance from threshold, an indicator variable for whether the raw score is above the specified threshold, an interaction of these two terms, and dummy variables for high school graduation cohort and examination year. The means below the thresholds represent the mean covariate values within 1 point of the boundary. Optimal

bandwidths are selected using the outcome, bachelor's degree within four years. 


\begin{tabular}{|c|c|c|c|c|c|c|c|}
\hline & \multicolumn{3}{|c|}{ All HS Years (2/3 Boundary) } & \multicolumn{3}{|c|}{ All HS Years (3/4 Boundary) } & \multirow[t]{2}{*}{$\begin{array}{c}\text { Distance from } \\
\text { Threshold }\end{array}$} \\
\hline & $\begin{array}{c}\text { Credit and } \\
\text { no credit }\end{array}$ & $\begin{array}{l}\text { Min credit } \\
\text { score }=3\end{array}$ & $\begin{array}{l}\text { Min credit } \\
\text { score } \neq 3\end{array}$ & $\begin{array}{c}\text { Credit and } \\
\text { no credit }\end{array}$ & $\begin{array}{c}\text { Min credit } \\
\text { score }=4\end{array}$ & $\begin{array}{l}\text { Min credit } \\
\text { score } \neq 4\end{array}$ & \\
\hline \multicolumn{8}{|l|}{ (A) Biology } \\
\hline Above threshold & $\begin{array}{l}0.008^{*} \\
(0.005)\end{array}$ & $\begin{array}{c}0.005 \\
(0.006)\end{array}$ & $\begin{array}{l}0.015^{*} \\
(0.008)\end{array}$ & $\begin{array}{c}0.007 \\
(0.005)\end{array}$ & $\begin{array}{l}-0.003 \\
(0.007)\end{array}$ & $\begin{array}{l}0.012^{* *} \\
(0.006)\end{array}$ & $\begin{array}{c}0.002 \\
(0.003)\end{array}$ \\
\hline Mean below threshold & 0.58 & 0.53 & 0.65 & 0.65 & 0.72 & 0.60 & 0.62 \\
\hline Bandwidth & 15.880 & 19.047 & 12.301 & 13.074 & 13.489 & 16.189 & 32.164 \\
\hline $\mathrm{N}$ & 197,284 & 123,736 & 71,204 & 175,659 & 72,979 & 123,634 & 389,484 \\
\hline \multicolumn{8}{|l|}{ (B) Calculus AB } \\
\hline Above threshold & $\begin{array}{c}0.013 * * * \\
(0.004)\end{array}$ & $\begin{array}{c}0.021 * * * \\
(0.005)\end{array}$ & $\begin{array}{c}0.001 \\
(0.006)\end{array}$ & $\begin{array}{l}0.008^{* *} \\
(0.003)\end{array}$ & $\begin{array}{c}0.022 * * * \\
(0.007)\end{array}$ & $\begin{array}{c}0.004 \\
(0.004)\end{array}$ & $\begin{array}{c}0.016^{* * *} \\
(0.003)\end{array}$ \\
\hline Mean below threshold & 0.56 & 0.51 & 0.65 & 0.61 & 0.68 & 0.58 & 0.57 \\
\hline Bandwidth & 11.644 & 10.461 & 21.561 & 15.669 & 10.624 & 16.199 & 15.844 \\
\hline $\mathrm{N}$ & 276,434 & 160,635 & 113,595 & 352,152 & 80,512 & 247,295 & 372,552 \\
\hline \multicolumn{8}{|l|}{ (C) Eng. Language and Comp. } \\
\hline Above threshold & $\begin{array}{c}0.009 * * * \\
(0.003)\end{array}$ & $\begin{array}{c}0.014^{* * *} \\
(0.004)\end{array}$ & $\begin{array}{c}0.005 \\
(0.004)\end{array}$ & $\begin{array}{c}0.002 \\
(0.003)\end{array}$ & $\begin{array}{l}-0.001 \\
(0.004)\end{array}$ & $\begin{array}{c}0.002 \\
(0.004)\end{array}$ & $\begin{array}{c}0.010^{* * *} \\
(0.002)\end{array}$ \\
\hline Mean below threshold & 0.54 & 0.49 & 0.63 & 0.67 & 0.75 & 0.63 & 0.59 \\
\hline Bandwidth & 19.766 & 18.993 & 29.980 & 18.899 & 19.753 & 21.104 & 26.038 \\
\hline $\mathrm{N}$ & 530,131 & 314,791 & 226,399 & 485,720 & 178,872 & 322,524 & 660,439 \\
\hline \multicolumn{8}{|l|}{ (D) Eng. Literature } \\
\hline Above threshold & $\begin{array}{c}0.007^{* * *} \\
(0.003)\end{array}$ & $\begin{array}{c}0.012^{* * *} \\
(0.004)\end{array}$ & $\begin{array}{c}0.003 \\
(0.004)\end{array}$ & $\begin{array}{l}0.007^{* *} \\
(0.003)\end{array}$ & $\begin{array}{l}0.009 * * \\
(0.004)\end{array}$ & $\begin{array}{c}0.006 \\
(0.004)\end{array}$ & $\begin{array}{c}0.007^{* * *} \\
(0.002)\end{array}$ \\
\hline Mean below threshold & 0.55 & 0.49 & 0.63 & 0.67 & 0.73 & 0.63 & 0.62 \\
\hline Bandwidth & 16.616 & 17.210 & 19.570 & 12.194 & 12.293 & 13.219 & 17.631 \\
\hline \multirow{2}{*}{\multicolumn{8}{|c|}{ (E) US Government }} \\
\hline & & & & & & & \\
\hline Above threshold & $\begin{array}{l}0.008^{* *} \\
(0.004)\end{array}$ & $\begin{array}{l}0.010 * * \\
(0.005)\end{array}$ & $\begin{array}{c}0.003 \\
(0.005)\end{array}$ & $\begin{array}{l}0.010^{* *} \\
(0.004)\end{array}$ & $\begin{array}{l}0.014^{* *} \\
(0.005)\end{array}$ & $\begin{array}{c}0.005 \\
(0.005)\end{array}$ & $\begin{array}{c}0.015 * * * \\
(0.003)\end{array}$ \\
\hline Mean below threshold & 0.57 & 0.51 & 0.66 & 0.67 & 0.74 & 0.62 & 0.61 \\
\hline Bandwidth & 18.058 & 19.310 & 19.787 & 14.605 & 15.580 & 15.451 & 26.225 \\
\hline $\mathrm{N}$ & 343,277 & 208,531 & 147,686 & 280,203 & 110,921 & 180,636 & 453,449 \\
\hline \multicolumn{8}{|l|}{ (F) US History } \\
\hline Above threshold & $\begin{array}{l}0.007 * * \\
(0.003)\end{array}$ & $\begin{array}{l}0.011 * * \\
(0.004)\end{array}$ & $\begin{array}{c}0.001 \\
(0.004)\end{array}$ & $\begin{array}{c}0.009 * * * \\
(0.003)\end{array}$ & $\begin{array}{c}0.013^{* * *} \\
(0.004)\end{array}$ & $\begin{array}{c}0.006 \\
(0.004)\end{array}$ & $\begin{array}{c}0.011^{* * *} \\
(0.002)\end{array}$ \\
\hline Mean below threshold & 0.57 & 0.50 & 0.65 & 0.67 & 0.73 & 0.61 & 0.61 \\
\hline Bandwidth & 14.588 & 15.417 & 17.347 & 18.200 & 18.560 & 19.743 & 33.363 \\
\hline $\mathrm{N}$ & 415,961 & 236,589 & 224,620 & 476,594 & 222,091 & 265,366 & 818,015 \\
\hline \multicolumn{8}{|c|}{ Notes: Heteroskedasticity robust standard errors in parentheses $\left({ }^{*} p<.10,{ }^{* *} p<.05,{ }^{* * *} p<.01\right)$. Includes AP exams taken by the } \\
\hline $\begin{array}{l}2004-2009 \text { cohorts. All regression } \\
\text { taken. Means represent the averag } \\
\text { attended a four-year coll ege withi } \\
\text { degrees from four-year colleges wi } \\
\text { scores of } 2 \text { and } 3 \text { included in } 2 / 3\end{array}$ & $\begin{array}{l}\text { ge use trian } \\
\text { in } 180 \text { days } \\
\text { vithin four } y\end{array}$ & $\begin{array}{l}\text { lar kernels w } \\
\text { e outcome wit } \\
\text { f HS graduatic } \\
\text { irs of graduat }\end{array}$ & $\begin{array}{l}\text { ith fixed effec } \\
\text { thin } 1 \text { raw po } \\
\text { on. Bachelor's } \\
\text { ting from high }\end{array}$ & ts for cohort & $\begin{array}{l}\text { and high sch } \\
\text { score. All stu } \\
\text { clude studen }\end{array}$ & $\begin{array}{l}\text { ol year i } \\
\text { ents in s } \\
\text { who res }\end{array}$ & $\begin{array}{l}\text { ch exam was } \\
\text { e first } \\
\text { d bachelor's } \\
\text { dicating }\end{array}$ \\
\hline
\end{tabular}


Table 5: RD Impacts on Bachelor's Attainment within 6 Years

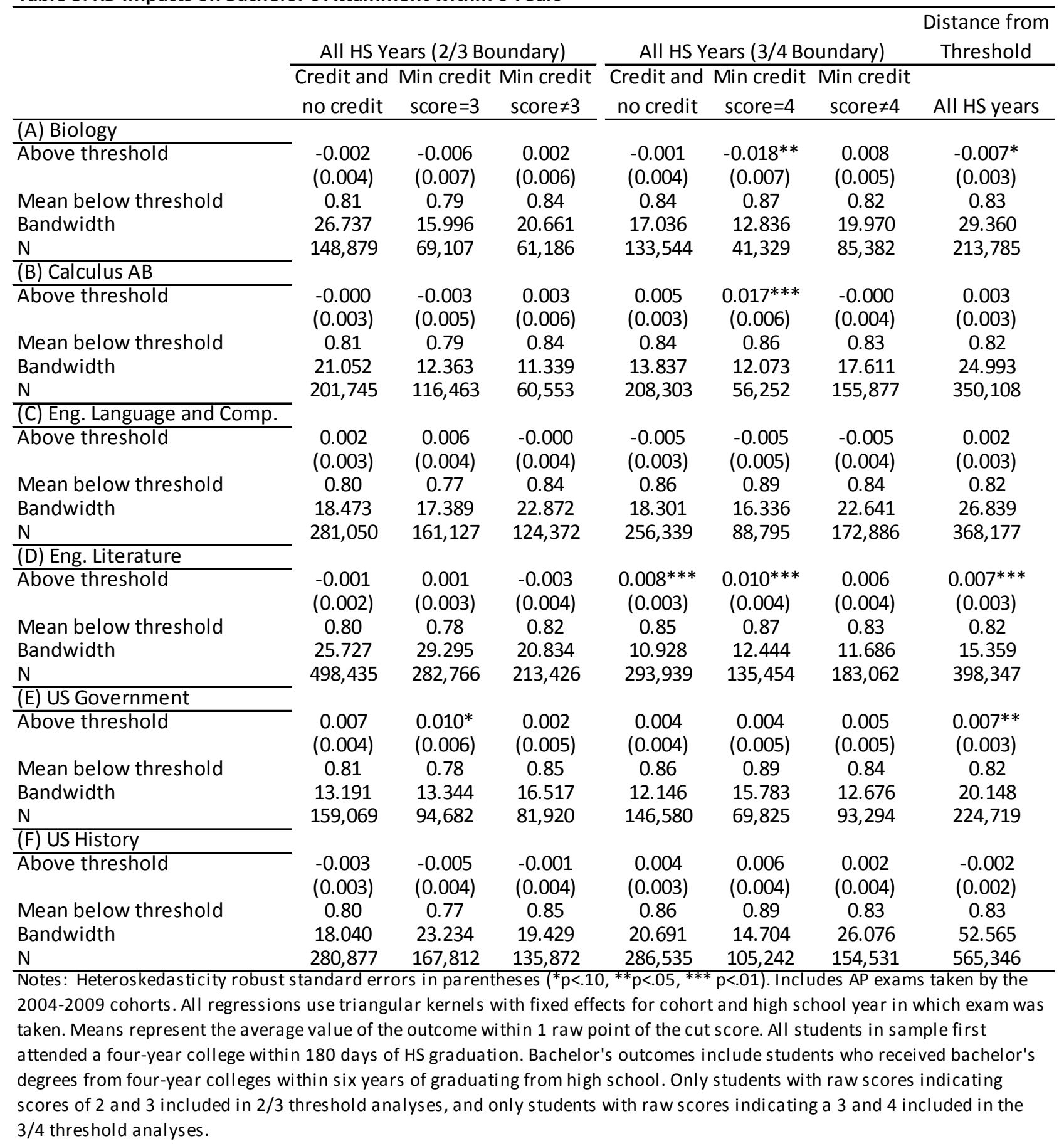


Table 6: RD Impacts on Bachelor's Attainment with 4 Years (Senior Exams Only)

\begin{tabular}{|c|c|c|c|c|c|c|c|}
\hline & \multirow{2}{*}{\multicolumn{3}{|c|}{ (2/3 Boundary) }} & \multirow{2}{*}{\multicolumn{3}{|c|}{ (3/4 Boundary) }} & Distance from \\
\hline & & & & & & & Threshold \\
\hline & & Min & Min & Credit & Min & Min & \\
\hline & $\begin{array}{c}\text { Credit and } \\
\text { no credit }\end{array}$ & $\begin{array}{l}\text { credit } \\
\text { score }=3\end{array}$ & $\begin{array}{c}\text { credit } \\
\text { score } \neq 3\end{array}$ & $\begin{array}{l}\text { and no } \\
\text { credit }\end{array}$ & $\begin{array}{l}\text { credit } \\
\text { score }=4\end{array}$ & $\begin{array}{l}\text { credit } \\
\text { score } \neq 4\end{array}$ & Senior Year \\
\hline (A) Biology & & & & & & & \\
\hline Above threshold & $\begin{array}{c}0.005 \\
(0.006)\end{array}$ & $\begin{array}{c}0.003 \\
(0.008)\end{array}$ & $\begin{array}{c}0.013 \\
(0.009)\end{array}$ & $\begin{array}{c}0.012 * * \\
(0.006)\end{array}$ & $\begin{array}{l}-0.003 \\
(0.008)\end{array}$ & $\begin{array}{c}0.022^{* * *} \\
(0.008)\end{array}$ & $\begin{array}{l}-0.001 \\
(0.004)\end{array}$ \\
\hline Mean below threshold & 0.58 & 0.54 & 0.64 & 0.65 & 0.72 & 0.60 & 0.63 \\
\hline Bandwidth & 17.571 & 20.088 & 13.059 & 17.122 & 25.306 & 16.989 & 30.985 \\
\hline $\mathrm{N}$ & 125,206 & 71,667 & 47,455 & 123,209 & 54,646 & 70,768 & 222,466 \\
\hline (B) Calculus AB & & & & & & & \\
\hline Above threshold & $\begin{array}{c}0.014 * * * \\
(0.004)\end{array}$ & $\begin{array}{c}0.024 * * * \\
(0.006)\end{array}$ & $\begin{array}{l}-0.001 \\
(0.006)\end{array}$ & $\begin{array}{c}0.008^{* *} \\
(0.004)\end{array}$ & $\begin{array}{c}0.022 * * * \\
(0.008)\end{array}$ & $\begin{array}{c}0.004 \\
(0.005)\end{array}$ & $\begin{array}{c}0.019 * * * \\
(0.004)\end{array}$ \\
\hline Mean below threshold & 0.56 & 0.51 & 0.65 & 0.61 & 0.68 & 0.58 & 0.57 \\
\hline Bandwidth & 12.187 & 10.972 & 26.802 & 15.682 & 10.647 & 16.589 & 15.514 \\
\hline $\mathrm{N}$ & 250,113 & 146,075 & 99,209 & 296,564 & 68,857 & 208,098 & 314,260 \\
\hline (C) Eng. Literature & & & & & & & \\
\hline Above threshold & $\begin{array}{c}0.009 * * * \\
(0.003)\end{array}$ & $\begin{array}{c}0.014^{* * *} \\
(0.003)\end{array}$ & $\begin{array}{c}0.003 \\
(0.004)\end{array}$ & $\begin{array}{c}0.007 * * \\
(0.003)\end{array}$ & $\begin{array}{l}0.008^{*} \\
(0.004)\end{array}$ & $\begin{array}{c}0.006 \\
(0.004)\end{array}$ & $\begin{array}{c}0.008 * * * \\
(0.002)\end{array}$ \\
\hline Mean below threshold & 0.55 & 0.49 & 0.63 & 0.67 & 0.73 & 0.63 & 0.62 \\
\hline Bandwidth & 18.489 & 18.935 & 24.163 & 12.508 & 12.711 & 13.392 & 18.347 \\
\hline $\mathrm{N}$ & 663,652 & 377,014 & 326,167 & 499,643 & 205,358 & 309,462 & 690,134 \\
\hline (D) US Government & & & & & & & \\
\hline Above threshold & $\begin{array}{l}0.008^{* *} \\
(0.004)\end{array}$ & $\begin{array}{l}0.009 * \\
(0.005)\end{array}$ & $\begin{array}{c}0.005 \\
(0.006)\end{array}$ & $\begin{array}{c}0.008^{* *} \\
(0.004)\end{array}$ & $\begin{array}{l}0.012 * * \\
(0.006)\end{array}$ & $\begin{array}{c}0.004 \\
(0.005)\end{array}$ & $\begin{array}{c}0.013^{* * *} \\
(0.003)\end{array}$ \\
\hline Mean below threshold & 0.57 & 0.51 & 0.66 & 0.66 & 0.74 & 0.61 & 0.61 \\
\hline Bandwidth & 19.920 & 20.534 & 20.585 & 15.621 & 15.662 & 16.007 & 25.959 \\
\hline $\mathrm{N}$ & 314,330 & 189,821 & 127,919 & 256,456 & 95,171 & 164,835 & 394,874 \\
\hline
\end{tabular}

Notes: Heteroskedasticity robust standard errors in parentheses $\left({ }^{*} p<.10,{ }^{* *} p<.05,{ }^{* * *} p<.01\right)$. Includes AP exams taken by the 2004-2009 cohorts. All regressions use triangular kernels with fixed effects for cohort and high school year in which exam was taken. Means represent the average value of the outcome within 1 raw point of the cut score. All students in sample first attended a four-year college within 180 days of HS graduation. Bachelor's outcomes include students who received bachelor's degrees from four-year colleges within four years of graduating from high school. Only students with raw scores indicating scores of 2 and 3 included in $2 / 3$ threshold analyses, and only students with raw scores 
Table 7: RD Impacts of Achieving Higher Junior Year AP Scores on Senior AP Test-Taking

\begin{tabular}{|c|c|c|c|c|c|c|c|c|c|c|c|c|}
\hline & \multicolumn{3}{|c|}{ Junior Year (1/2 Boundary) } & \multicolumn{3}{|c|}{ Junior Year (2/3 Boundary) } & \multicolumn{3}{|c|}{ Junior Year (3/4 Boundary) } & \multicolumn{3}{|c|}{ Junior Year (4/5 Boundary) } \\
\hline & \# Exams & \#3+Scores & $\# 4+$ Scores & \# Exams & $\# 3+$ & $\# 4+$ & \# Exams & \#3+Scores & \# 4 + Scores & \# Exams & \#3+Scores & \# 4+Scores \\
\hline & Sen. Year & Sen. Year & Sen. Year & Sen. Year & Scores & Scores & Sen. Year & Sen. Year & Sen. Year & Sen. Year & Sen. Year & Sen. Year \\
\hline \multicolumn{13}{|l|}{ (A) Biology } \\
\hline Above threshold & $\begin{array}{c}0.024 \\
(0.024)\end{array}$ & $\begin{array}{c}0.013 \\
(0.016)\end{array}$ & $\begin{array}{r}-0.003 \\
(0.009)\end{array}$ & $\begin{array}{c}0.084^{* * *} \\
(0.023)\end{array}$ & $\begin{array}{l}0.052^{* *} \\
(0.021)\end{array}$ & $\begin{array}{c}0.016 \\
(0.015)\end{array}$ & $\begin{array}{c}0.034 \\
(0.022)\end{array}$ & $\begin{array}{c}0.024 \\
(0.021)\end{array}$ & $\begin{array}{c}0.007 \\
(0.017)\end{array}$ & $\begin{array}{c}0.010 \\
(0.023)\end{array}$ & $\begin{array}{c}0.018 \\
(0.021)\end{array}$ & $\begin{array}{c}0.015 \\
(0.021)\end{array}$ \\
\hline Mean below threshold & 1.39 & 0.52 & 0.18 & 1.68 & 0.98 & 0.45 & 2.12 & 1.56 & 0.88 & 2.65 & 2.30 & 1.59 \\
\hline Bandwidth & 16.697 & 14.100 & 13.884 & 14.532 & 11.162 & 9.360 & 17.624 & 14.069 & 13.261 & 22.501 & 24.687 & 19.901 \\
\hline \multicolumn{13}{|l|}{ (B) Calculus AB } \\
\hline Above threshold & $\begin{array}{c}0.090 * * * \\
(0.031)\end{array}$ & $\begin{array}{l}0.048^{* *} \\
(0.022)\end{array}$ & $\begin{array}{c}0.023 \\
(0.016)\end{array}$ & $\begin{array}{l}0.058^{*} \\
(0.034)\end{array}$ & $\begin{array}{c}0.013 \\
(0.025)\end{array}$ & $\begin{array}{c}0.005 \\
(0.018)\end{array}$ & $\begin{array}{c}0.005 \\
(0.029)\end{array}$ & $\begin{array}{c}0.002 \\
(0.028)\end{array}$ & $\begin{array}{c}0.014 \\
(0.021)\end{array}$ & $\begin{array}{l}0.057^{* *} \\
(0.025)\end{array}$ & $\begin{array}{l}0.056^{* *} \\
(0.024)\end{array}$ & $\begin{array}{c}0.070^{* * *} \\
(0.026)\end{array}$ \\
\hline Mean below threshold & 1.64 & 0.79 & 0.34 & 1.93 & 1.20 & 0.57 & 2.27 & 1.71 & 0.95 & 2.60 & 2.25 & 1.58 \\
\hline Bandwidth & 19.004 & 19.844 & 14.085 & 11.253 & 14.116 & 15.001 & 14.614 & 12.481 & 14.578 & 23.387 & 21.016 & 12.203 \\
\hline$\frac{\mathrm{N}}{\text { (C) Eng. Language and Comp. }}$ & 43,759 & 44,514 & 38,333 & 41,466 & 48,904 & 49,460 & 62,198 & 54,976 & 62,051 & 81,324 & 78,435 & 55,687 \\
\hline Above threshold & $\begin{array}{c}0.004 \\
(0.011)\end{array}$ & $\begin{array}{c}0.004 \\
(0.006)\end{array}$ & $\begin{array}{r}-0.000 \\
(0.003)\end{array}$ & $\begin{array}{c}0.143 * * * \\
(0.011)\end{array}$ & $\begin{array}{c}0.089 * * * \\
(0.009)\end{array}$ & $\begin{array}{c}0.025 * * * \\
(0.006)\end{array}$ & $\begin{array}{c}0.054^{* * *} \\
(0.012)\end{array}$ & $\begin{array}{c}0.039 * * * \\
(0.012)\end{array}$ & $\begin{array}{r}-0.004 \\
(0.013)\end{array}$ & $\begin{array}{c}0.020 \\
(0.018)\end{array}$ & $\begin{array}{c}0.027 \\
(0.017)\end{array}$ & $\begin{array}{l}0.037^{* *} \\
(0.018)\end{array}$ \\
\hline Mean below threshold & 1.18 & 0.16 & 0.06 & 1.72 & 0.88 & 0.34 & 2.47 & $1.95^{\prime}$ & 1.16 & 2.96 & 2.64 & 2.03 \\
\hline Bandwidth & 19.795 & 8.556 & 8.872 & 13.145 & 10.596 & 8.968 & 13.981 & 11.723 & 7.554 & 11.877 & 12.796 & 11.295 \\
\hline \multicolumn{13}{|l|}{ (D) Eng. Literature } \\
\hline Above threshold & $\begin{array}{l}0.071 * * \\
(0.028)\end{array}$ & $\begin{array}{c}0.008 \\
(0.013)\end{array}$ & $\begin{array}{c}0.013 \\
(0.010)\end{array}$ & $\begin{array}{c}0.106^{* * *} \\
(0.025)\end{array}$ & $\begin{array}{c}0.082^{* * *} \\
(0.020)\end{array}$ & $\begin{array}{c}0.025^{* *} \\
(0.012)\end{array}$ & $\begin{array}{c}0.043 \\
(0.032)\end{array}$ & $\begin{array}{c}0.014 \\
(0.031)\end{array}$ & $\begin{array}{c}0.002 \\
(0.028)\end{array}$ & $\begin{array}{c}0.038 \\
(0.042)\end{array}$ & $\begin{array}{c}0.026 \\
(0.042)\end{array}$ & $\begin{array}{c}0.021 \\
(0.039)\end{array}$ \\
\hline Mean below threshold & 0.79 & 0.11 & 0.03 & 1.13 & 0.66 & 0.31 & 1.65 & 1.35 & 0.91 & 2.02 & 1.85 & 1.46 \\
\hline Bandwidth & 26.334 & 18.011 & 11.417 & 18.008 & 17.549 & 27.220 & 15.333 & 13.518 & 11.884 & 23.141 & 20.279 & 19.347 \\
\hline $\mathrm{N}$ & 34,356 & 21,942 & 13,447 & 50,616 & 49,611 & 60,144 & 41,860 & 37,219 & 32,957 & 27,152 & 26,912 & 26,793 \\
\hline \multicolumn{13}{|l|}{ (E) US Government } \\
\hline Above threshold & $\begin{array}{c}0.013 \\
(0.032)\end{array}$ & $\begin{array}{c}0.012 \\
(0.023)\end{array}$ & $\begin{array}{r}-0.015 \\
(0.011)\end{array}$ & $\begin{array}{c}0.075^{* *} \\
(0.030)\end{array}$ & $\begin{array}{c}0.036 \\
(0.025)\end{array}$ & $\begin{array}{r}-0.001 \\
(0.019)\end{array}$ & $\begin{array}{l}-0.020 \\
(0.042)\end{array}$ & $\begin{array}{r}-0.004 \\
(0.038)\end{array}$ & $\begin{array}{r}-0.011 \\
(0.032)\end{array}$ & $\begin{array}{l}-0.015 \\
(0.047)\end{array}$ & $\begin{array}{r}-0.016 \\
(0.052)\end{array}$ & $\begin{array}{l}-0.008 \\
(0.054)\end{array}$ \\
\hline Mean below threshold & 1.00 & 0.35 & 0.11 & 1.53 & 1.03 & 0.52 & 2.18 & 1.84 & 1.20 & 2.81 & 2.61 & 2.15 \\
\hline Bandwidth & 23.714 & 15.898 & 22.161 & 19.989 & 21.958 & 21.042 & 12.167 & 13.598 & 15.059 & 20.918 & 14.172 & 12.105 \\
\hline$\frac{\mathrm{N}}{(\mathrm{F}) \text { US History }}$ & 28,085 & 19,216 & 26,547 & 38,340 & 39,612 & 39,178 & 24,750 & 27,176 & 29,270 & 19,824 & 17,577 & 15,626 \\
\hline Above threshold & $\begin{array}{c}0.021 * * * \\
(0.008)\end{array}$ & $\begin{array}{l}-0.001 \\
(0.006)\end{array}$ & $\begin{array}{l}-0.005^{*} \\
(0.003)\end{array}$ & $\begin{array}{c}0.083 * * * \\
(0.010)\end{array}$ & $\begin{array}{c}0.035^{* * *} \\
(0.009)\end{array}$ & $\begin{array}{c}0.003 \\
(0.006)\end{array}$ & $\begin{array}{c}0.055^{* * *} \\
(0.011)\end{array}$ & $\begin{array}{c}0.055^{* * *} \\
(0.011)\end{array}$ & $\begin{array}{c}0.029 * * * \\
(0.008)\end{array}$ & $\begin{array}{l}0.031^{* *} \\
(0.015)\end{array}$ & $\begin{array}{l}0.034^{* *} \\
(0.015)\end{array}$ & $\begin{array}{c}0.033^{* *} \\
(0.016)\end{array}$ \\
\hline Mean below threshold & 1.38 & 0.45 & 0.15 & 1.81 & 1.09 & 0.48 & 2.36 & 1.81 & 1.04 & 2.96 & 2.66 & 2.01 \\
\hline Bandwidth & 27.585 & 14.285 & 15.558 & 13.946 & 10.723 & 11.596 & 15.017 & 12.806 & 14.560 & 15.349 & 15.188 & 11.403 \\
\hline $\mathrm{N}$ & 551,785 & 343,508 & 372,520 & 432,254 & 336,000 & 362,049 & 412,516 & 353,936 & 400,503 & 242,366 & 239,834 & 179,247 \\
\hline
\end{tabular}

2009 cohorts. All regressions use triangular kernels with fixed effects for cohort and high school year in which exam was taken. Means represent the average value of the outcome within

1 raw point of the cut score. Only students with raw scores indicating scores of 2 and 3 included in $2 / 3$ threshold analyses, and only students with raw scores indicating a 3 and 4

included in the $3 / 4$ threshold analyses, and so on. 
Table 8: Regression Discontinuity Impacts on SAT Score Sending and SAT Scores of First College Attended

RD Impacts on SAT Score Sending

RD Average SAT Scores of Colleges (First-Time On-Time Students)

\begin{tabular}{|c|c|c|c|c|c|c|c|c|c|c|c|c|}
\hline \multirow[b]{3}{*}{ Boundary } & & & & & & & \\
\hline & \multicolumn{2}{|c|}{ All HS Years } & \multicolumn{2}{|c|}{ Junior Takers } & \multicolumn{2}{|c|}{ Senior Takers } & \multicolumn{2}{|c|}{ All HS Years } & \multicolumn{2}{|c|}{ Junior Takers } & \multicolumn{2}{|c|}{ Senior Takers } \\
\hline & $2 / 3$ & $3 / 4$ & $2 / 3$ & $3 / 4$ & $2 / 3$ & $3 / 4$ & $2 / 3$ & $3 / 4$ & $2 / 3$ & $3 / 4$ & $2 / 3$ & $3 / 4$ \\
\hline (A) Biology & & & & & & & & & & & & \\
\hline Above threshold & $\begin{array}{c}0.006 \\
(0.031)\end{array}$ & $\begin{array}{c}0.019 \\
(0.042)\end{array}$ & $\begin{array}{c}0.085 \\
(0.060)\end{array}$ & $\begin{array}{c}0.114^{*} \\
(0.068)\end{array}$ & $\begin{array}{l}-0.032 \\
(0.041)\end{array}$ & $\begin{array}{l}-0.018 \\
(0.055)\end{array}$ & $\begin{array}{c}0.747 \\
(1.179)\end{array}$ & $\begin{array}{c}0.064 \\
(1.308)\end{array}$ & $\begin{array}{c}3.641 * * \\
(1.839)\end{array}$ & $\begin{array}{r}-0.170 \\
(2.107)\end{array}$ & $\begin{array}{r}-0.470 \\
(1.485)\end{array}$ & $\begin{array}{c}0.467 \\
(1.678)\end{array}$ \\
\hline Mean below threshold & 4.543 & 5.192 & 4.701 & 5.529 & 4.434 & 4.929 & $1,168.84$ & $1,204.20$ & $1,166.22$ & $1,209.34$ & $1,168.71$ & $1,199.85$ \\
\hline Bandwidth & 35.194 & 13.541 & 19.309 & 15.047 & 22.025 & 13.604 & 13.066 & 10.872 & 15.839 & 11.564 & 13.899 & 11.581 \\
\hline $\mathrm{N}$ & 285,186 & 214,072 & 93,212 & 83,295 & 164,712 & 123,805 & 168,237 & 143,947 & 65,194 & 54,470 & 105,901 & 88,278 \\
\hline (B) Calculus AB & & & & & & & & & & & & \\
\hline Above threshold & $\begin{array}{c}-0.020 \\
(0.035)\end{array}$ & $\begin{array}{c}-0.014 \\
(0.026)\end{array}$ & $\begin{array}{c}-0.073 \\
(0.095)\end{array}$ & $\begin{array}{c}0.007 \\
(0.071)\end{array}$ & $\begin{array}{c}-0.022 \\
(0.037)\end{array}$ & $\begin{array}{c}-0.018 \\
(0.029)\end{array}$ & $\begin{array}{c}-1.072 \\
(1.217)\end{array}$ & $\begin{array}{l}-0.480 \\
(0.797)\end{array}$ & $\begin{array}{l}-2.249 \\
(3.063)\end{array}$ & $\begin{array}{c}-0.884 \\
(2.373)\end{array}$ & $\begin{array}{r}-1.219 \\
(1.288)\end{array}$ & $\begin{array}{l}-0.326 \\
(0.855)\end{array}$ \\
\hline Mean below threshold & 4.436 & 4.833 & 4.987 & 5.488 & 4.351 & 4.714 & $1,177.47$ & $1,199.79$ & $1,191.79$ & $1,219.22$ & $1,175.39$ & $1,195.99$ \\
\hline Bandwidth & 8.860 & 36.998 & 10.452 & 27.031 & 9.506 & 19.336 & 6.973 & 17.730 & 9.344 & 12.622 & 7.074 & 19.108 \\
\hline $\mathrm{N}$ & 259,120 & 429,387 & 38,575 & 65,505 & 242,559 & 360,771 & 162,568 & 350,195 & 27,200 & 45,266 & 143,898 & 294,461 \\
\hline (C) Eng. Language & & & & & & & & & & & & \\
\hline Above threshold & $\begin{array}{c}0.086^{* * *} \\
(0.022)\end{array}$ & $\begin{array}{c}0.023 \\
(0.025)\end{array}$ & $\begin{array}{c}0.105^{* * *} \\
(0.026)\end{array}$ & $\begin{array}{c}0.019 \\
(0.029)\end{array}$ & $\begin{array}{c}0.034 \\
(0.045)\end{array}$ & $\begin{array}{c}0.038 \\
(0.049)\end{array}$ & $\begin{array}{c}0.736 \\
(0.627)\end{array}$ & $\begin{array}{c}1.810^{* *} \\
(0.793)\end{array}$ & $\begin{array}{c}0.853 \\
(0.690)\end{array}$ & $\begin{array}{c}2.494^{* * *} \\
(0.858)\end{array}$ & $\begin{array}{r}-1.096 \\
(1.671)\end{array}$ & $\begin{array}{c}-0.183 \\
(1.887)\end{array}$ \\
\hline Mean below threshold & 3.892 & 5.135 & 4.000 & 5.389 & 3.366 & 4.219 & $1,146.19$ & $1,204.38$ & $1,147.35$ & $1,208.38$ & $1,139.68$ & $1,187.74$ \\
\hline Bandwidth & 15.231 & 17.107 & 13.454 & 16.253 & 20.505 & 22.747 & 20.062 & 14.116 & 20.515 & 15.547 & 15.196 & 11.618 \\
\hline $\mathrm{N}$ & 547,895 & 548,476 & 396,035 & 415,435 & 129,791 & 124,835 & 522,900 & 387,741 & 427,644 & 332,128 & 74,036 & 65,990 \\
\hline (D) Eng. Literature & & & & & & & & & & & & \\
\hline$\overline{\mathrm{Abov}}$ & $\begin{array}{c}0.004 \\
(0.016)\end{array}$ & $\begin{array}{c}0.058^{* * *} \\
(0.020)\end{array}$ & $\begin{array}{c}0.026 \\
(0.082)\end{array}$ & $\begin{array}{c}0.056 \\
(0.100)\end{array}$ & $\begin{array}{c}-0.001 \\
(0.018)\end{array}$ & $\begin{array}{c}0.059 * * * \\
(0.020)\end{array}$ & $\begin{array}{c}0.937 \\
(0.619)\end{array}$ & $\begin{array}{l}-0.435 \\
(0.563)\end{array}$ & $\begin{array}{c}3.069 \\
(2.299)\end{array}$ & $\begin{array}{r}-1.333 \\
(3.207)\end{array}$ & $\begin{array}{c}0.726 \\
(0.623)\end{array}$ & $\begin{array}{c}-0.426 \\
(0.564)\end{array}$ \\
\hline Mea & 4.088 & 4.99 & 3.843 & 5.273 & 4.102 & 4.973 & $1,152.11$ & $1,203.33$ & 1,16 & $1,238.43$ & $1,151.24$ & $1,201.22$ \\
\hline Bandwidth & 24.727 & 17.673 & 16.311 & 15.386 & 20.245 & 18.275 & 15.346 & 21.295 & 22.263 & 12.718 & 15.983 & 25.313 \\
\hline $\mathrm{N}$ & $1,000,818$ & 830,268 & 46,555 & 41,964 & 887,753 & 796,391 & 581,905 & 729,872 & 42,693 & 28,716 & 569,373 & 688,392 \\
\hline (E) US Government & & & & & & & & & & & & \\
\hline Above threshold & $\begin{array}{c}0.031 \\
(0.025)\end{array}$ & $\begin{array}{c}0.033 \\
(0.037)\end{array}$ & $\begin{array}{c}0.018 \\
(0.082)\end{array}$ & $\begin{array}{c}-0.037 \\
(0.119)\end{array}$ & $\begin{array}{c}0.032 \\
(0.026)\end{array}$ & $\begin{array}{c}0.018 \\
(0.036)\end{array}$ & $\begin{array}{c}1.254^{*} \\
(0.738)\end{array}$ & $\begin{array}{c}0.494 \\
(1.159)\end{array}$ & $\begin{array}{c}-1.047 \\
(2.369)\end{array}$ & $\begin{array}{r}-0.390 \\
(3.383)\end{array}$ & $\begin{array}{l}1.640 * * \\
(0.798)\end{array}$ & $\begin{array}{c}0.485 \\
(1.146)\end{array}$ \\
\hline Mean below & 4.655 & 5.316 & 3.232 & 4.188 & 4.798 & 5.419 & $1,166.78$ & $1,210.21$ & $1,172.00$ & $1,219.26$ & $1,164.93$ & $1,207.66$ \\
\hline Bandwidth & 23.200 & 10.724 & 23.001 & 12.565 & 28.196 & 13.073 & 22.581 & 9.003 & 29.968 & 12.928 & 21.729 & 10.537 \\
\hline $\mathrm{N}$ & 458,928 & 253,654 & 40,161 & 25,424 & 416,966 & 263,416 & 362,886 & 183,143 & 32,928 & 21,802 & 315,299 & 186,085 \\
\hline (F) U & & & & & & & & & & & & \\
\hline Above threshold & $\begin{array}{c}0.026 \\
(0.025)\end{array}$ & $\begin{array}{c}0.035 \\
(0.025)\end{array}$ & $\begin{array}{c}0.034 \\
(0.027)\end{array}$ & $\begin{array}{c}0.041 \\
(0.029)\end{array}$ & $\begin{array}{c}-0.084 \\
(0.077)\end{array}$ & $\begin{array}{l}-0.026 \\
(0.103)\end{array}$ & $\begin{array}{c}0.318 \\
(0.724)\end{array}$ & $\begin{array}{c}0.706 \\
(0.744)\end{array}$ & $\begin{array}{c}0.476 \\
(0.681)\end{array}$ & $\begin{array}{c}0.579 \\
(0.832)\end{array}$ & $\begin{array}{r}-4.103 \\
(3.140)\end{array}$ & $\begin{array}{c}2.841 \\
(3.049)\end{array}$ \\
\hline Mean below & 4.281 & 5.172 & 4.414 & 5.301 & 3.573 & 4.372 & $1,163.06$ & $1,204.42$ & $1,162.65$ & $1,205.04$ & $1,152.29$ & $1,184.05$ \\
\hline Bandwidth & 13.524 & 18.564 & 13.423 & 15.242 & 20.144 & 15.402 & 15.114 & 17.163 & 20.239 & 15.672 & 11.899 & 15.906 \\
\hline $\mathrm{N}$ & 484,016 & 570,072 & 416,703 & 418,452 & 48,213 & 35,172 & 418,976 & 446,124 & 448,537 & 355,465 & 23,565 & 28,680 \\
\hline
\end{tabular}

kernels with fixed effects for cohort and high school year in which exam was taken. Means represent the average value of the outcome within 1 raw point of the cut score. Only students with raw scores indicating scores of 2 and 3 included in $2 / 3$ threshold analyses, and only students with raw scores indicating a 3 and 4 included in the $3 / 4$ threshold analyses. 
Table 9: Marginal Impacts of Passing an Additional AP Exam, Based on College Policy

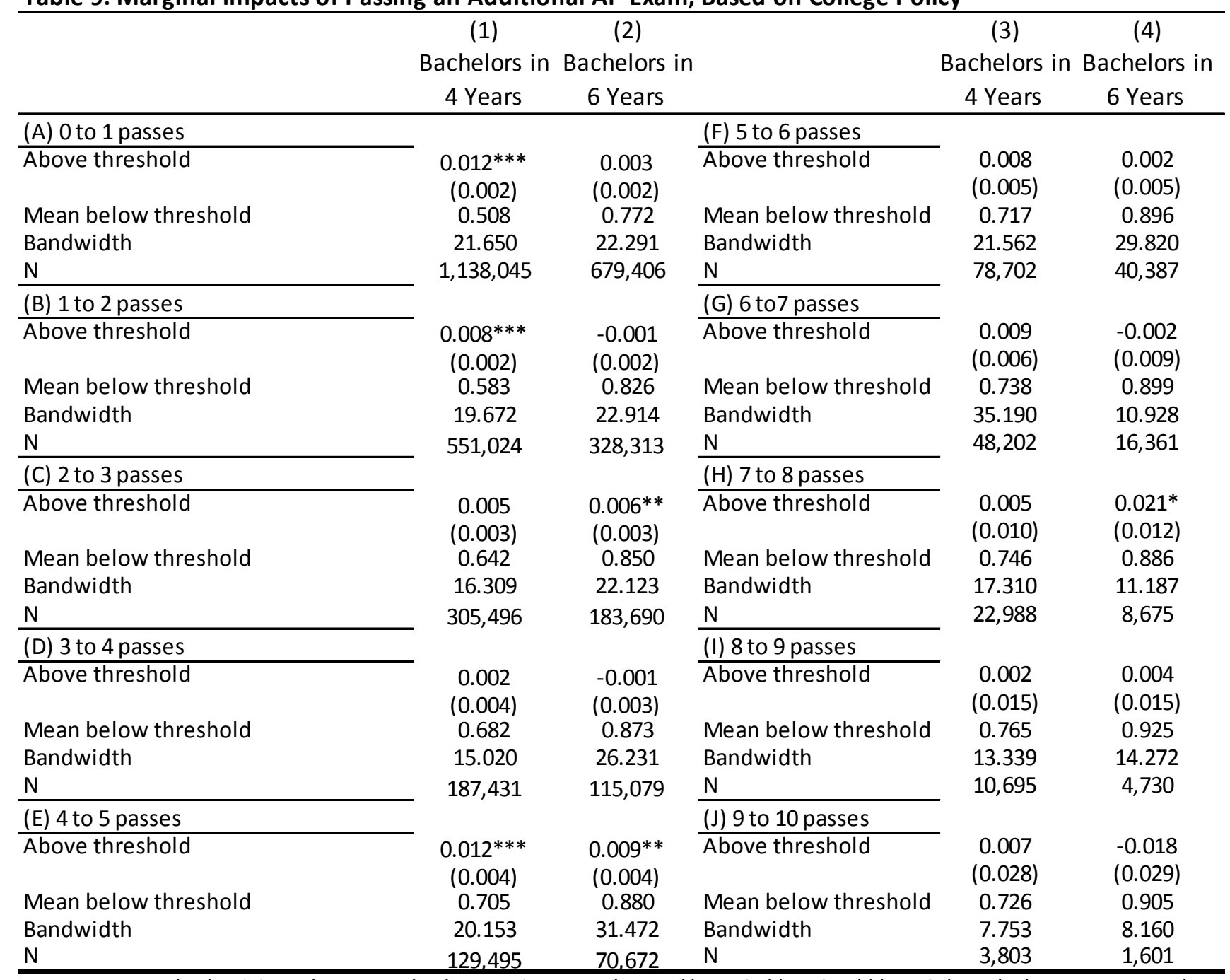

Notes: Heteroskedasticity robust standard errors in parentheses $\left({ }^{*} p<.10,{ }^{* *} p<.05,{ }^{* * *} p<.01\right)$. Includes AP exams taken by the 2004-2009 cohorts. All regressions use triangular kernels with fixed effects for cohort and high school year by subject. Means represent the average value of the outcome within 1 raw point of the cut score. Sample only includes students who began at four-year institutions with AP credit policies within 180 days of HS graduation, and students for whom all integer AP exam scores were matched to raw AP scores. 
Table 10: RD Impacts on Bachelor's Attainment by Parental Income

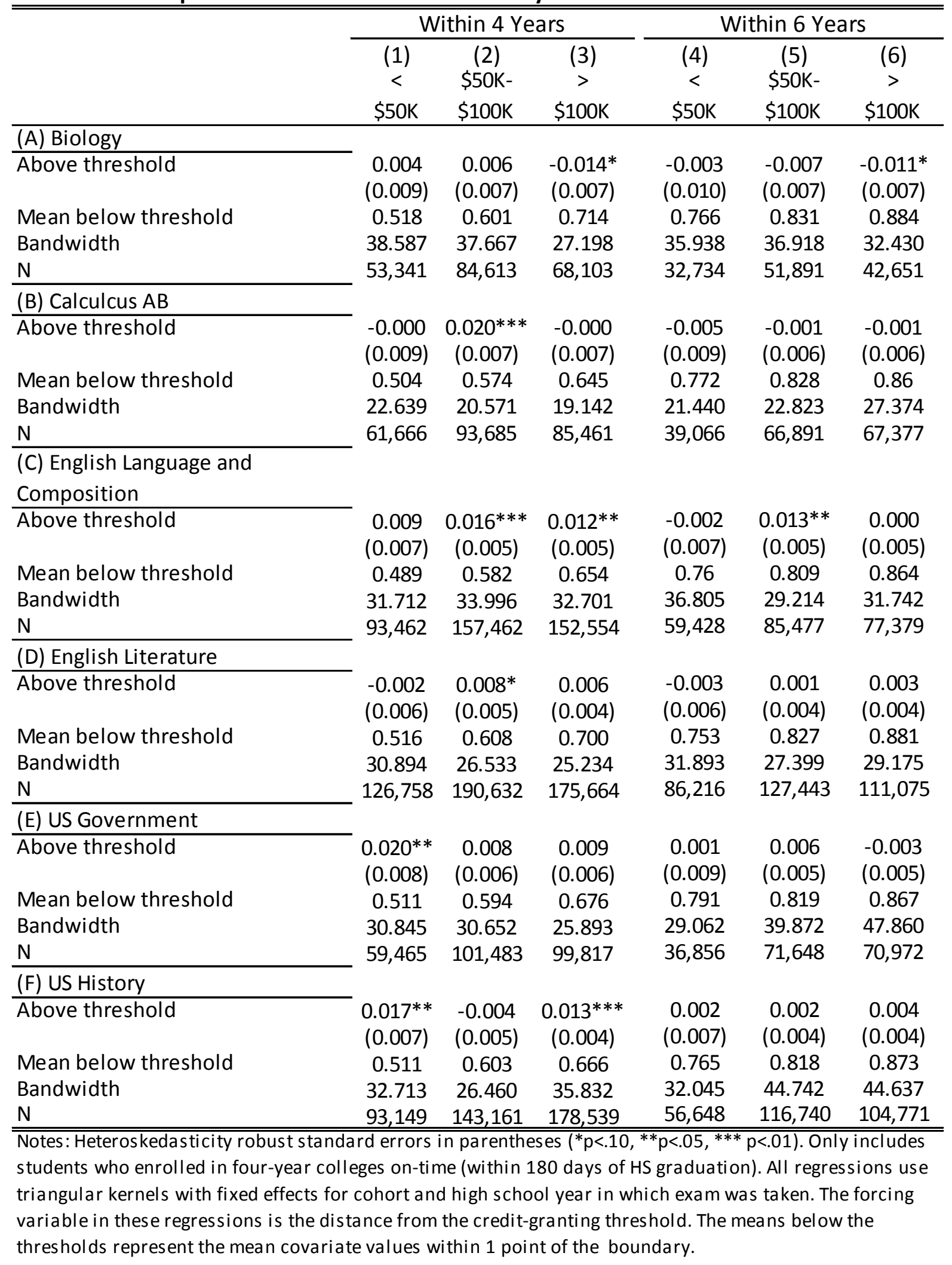


Figure 1: Distribution of Distances from College-Specific Credit-Granting Thresholds
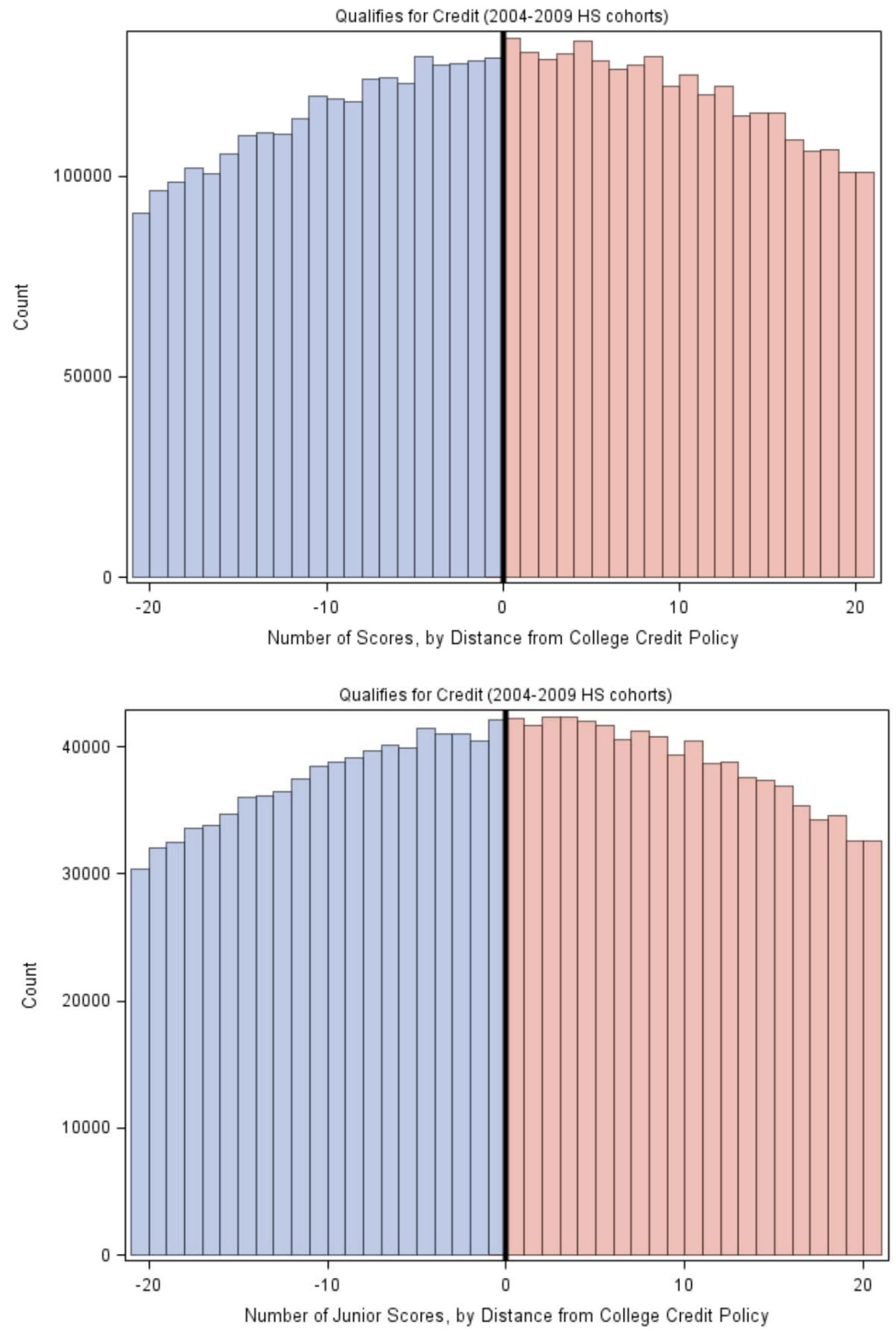
Figure 2: Parameter estimates and t-statistics associated receiving a credit-granting AP exam score
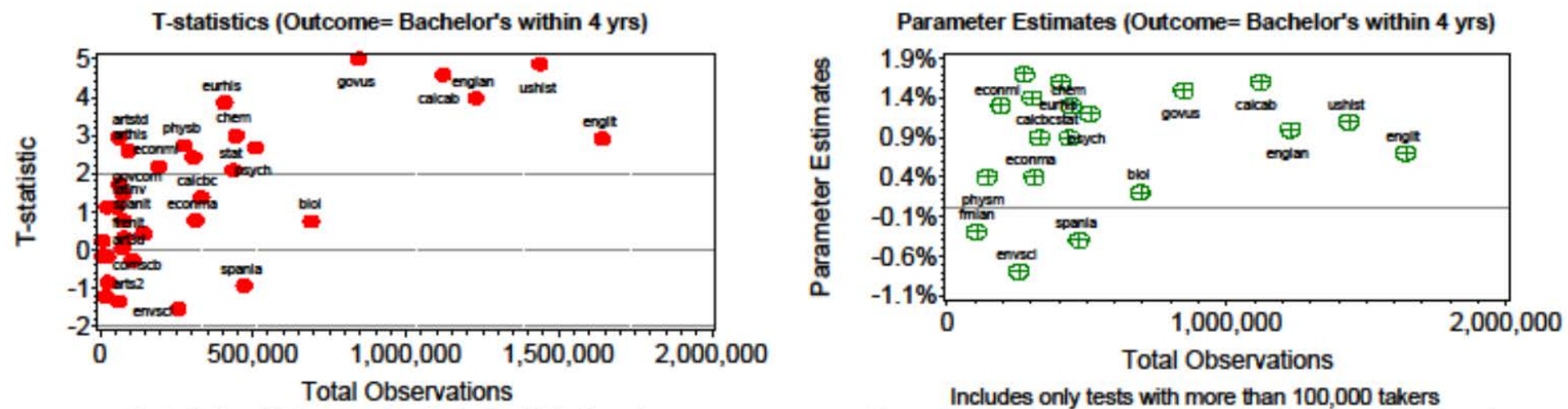

T-statistics (Outcome= Bachelor's within 5 yrs)

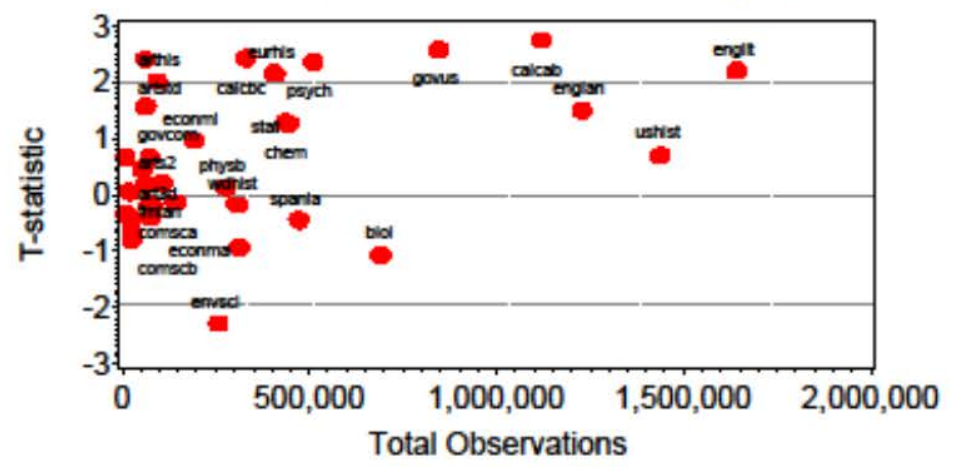

Parameter Estimates (Outcome= Bachelor's within $5 \mathrm{yrs}$ )

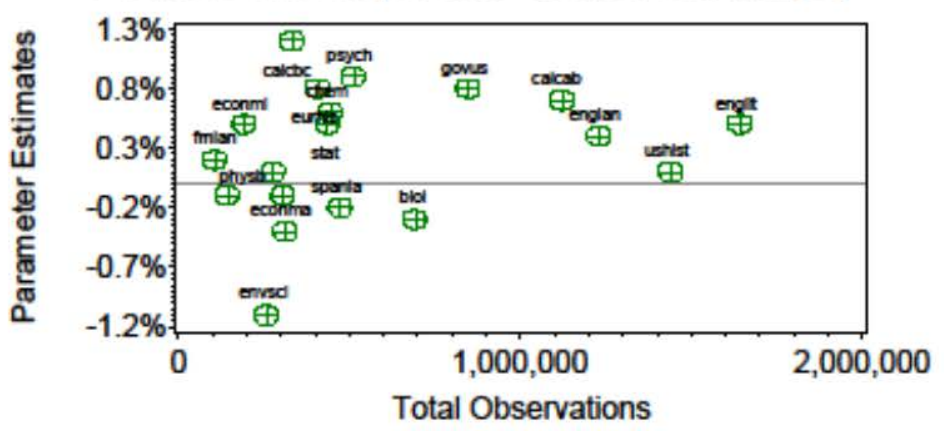

T-statistics (Outcome= Bachelor's within 6 yrs)

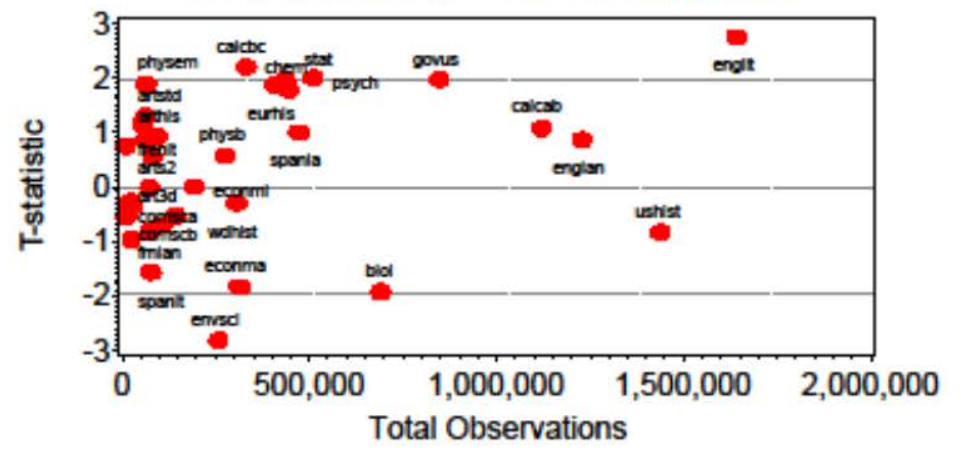

Includes only tests with more than 100,000 takers

Parameter Estimates (Outcome $=$ Bachelor's within 6 yrs)

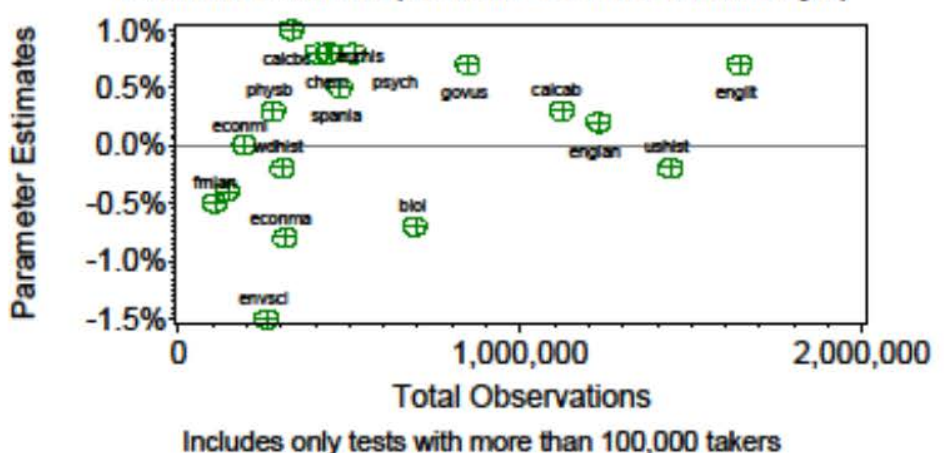


Figure 3: Number of Senior Year AP Exams Taken and Scores of 3 or Higher on These Exams, by Distance from the 2/3 threshold on Junior Exams
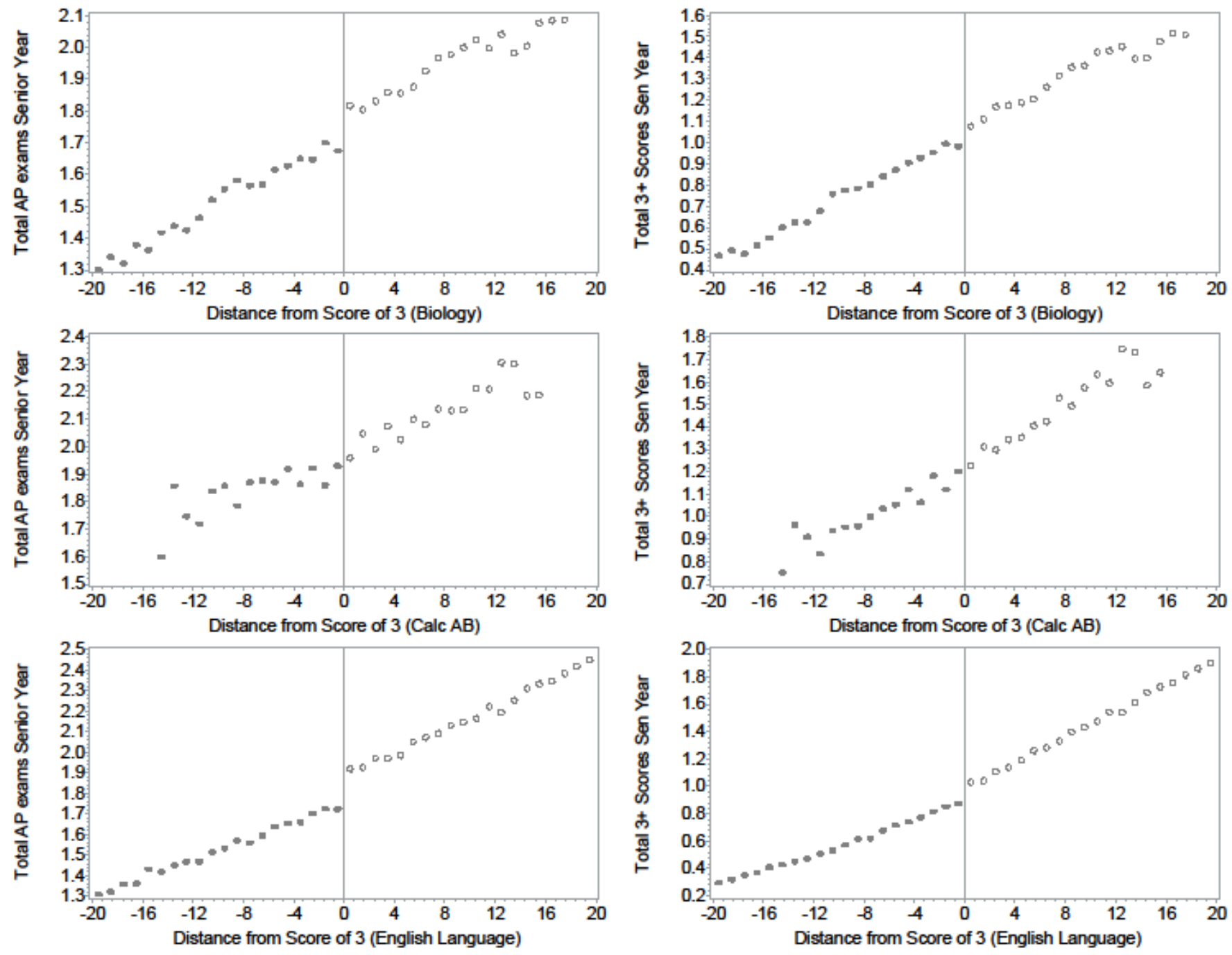

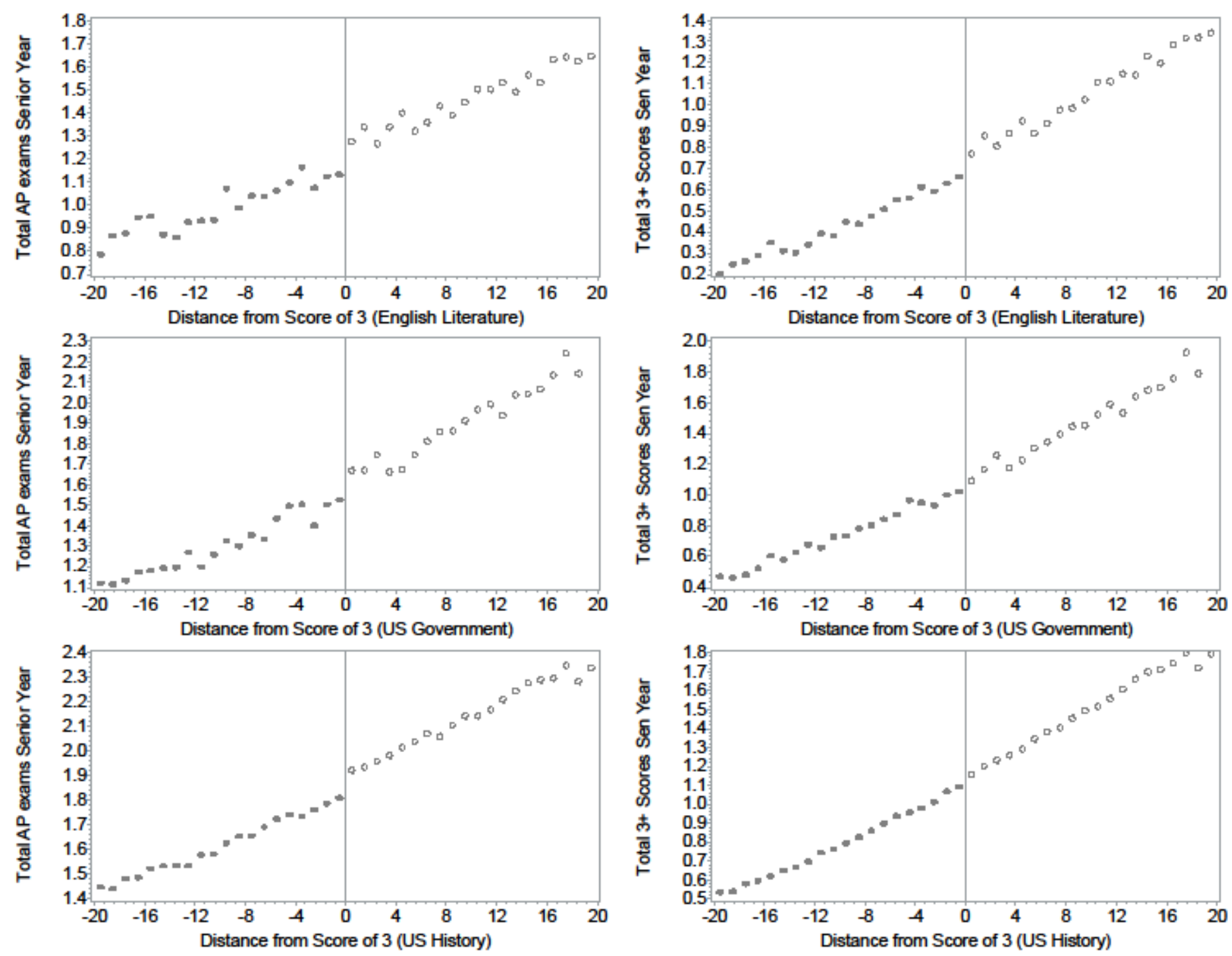
Figure 4: Multidimensional RD Parameter Estimates

Percent increase bachelor's completion rates

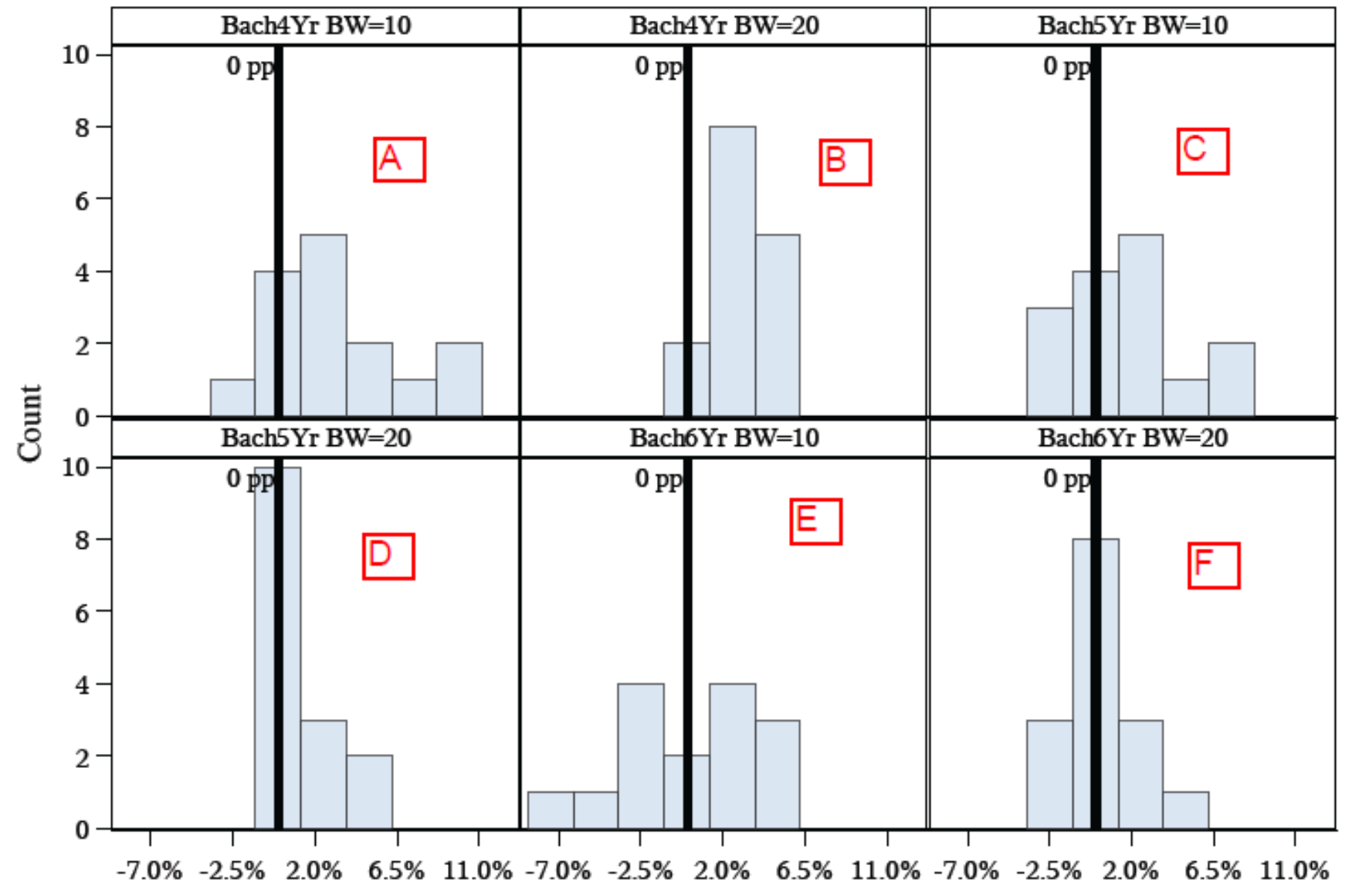


Appendix Figure A1: On-time bachelor's degree attainment rates, by distance from credit-granting thresholds
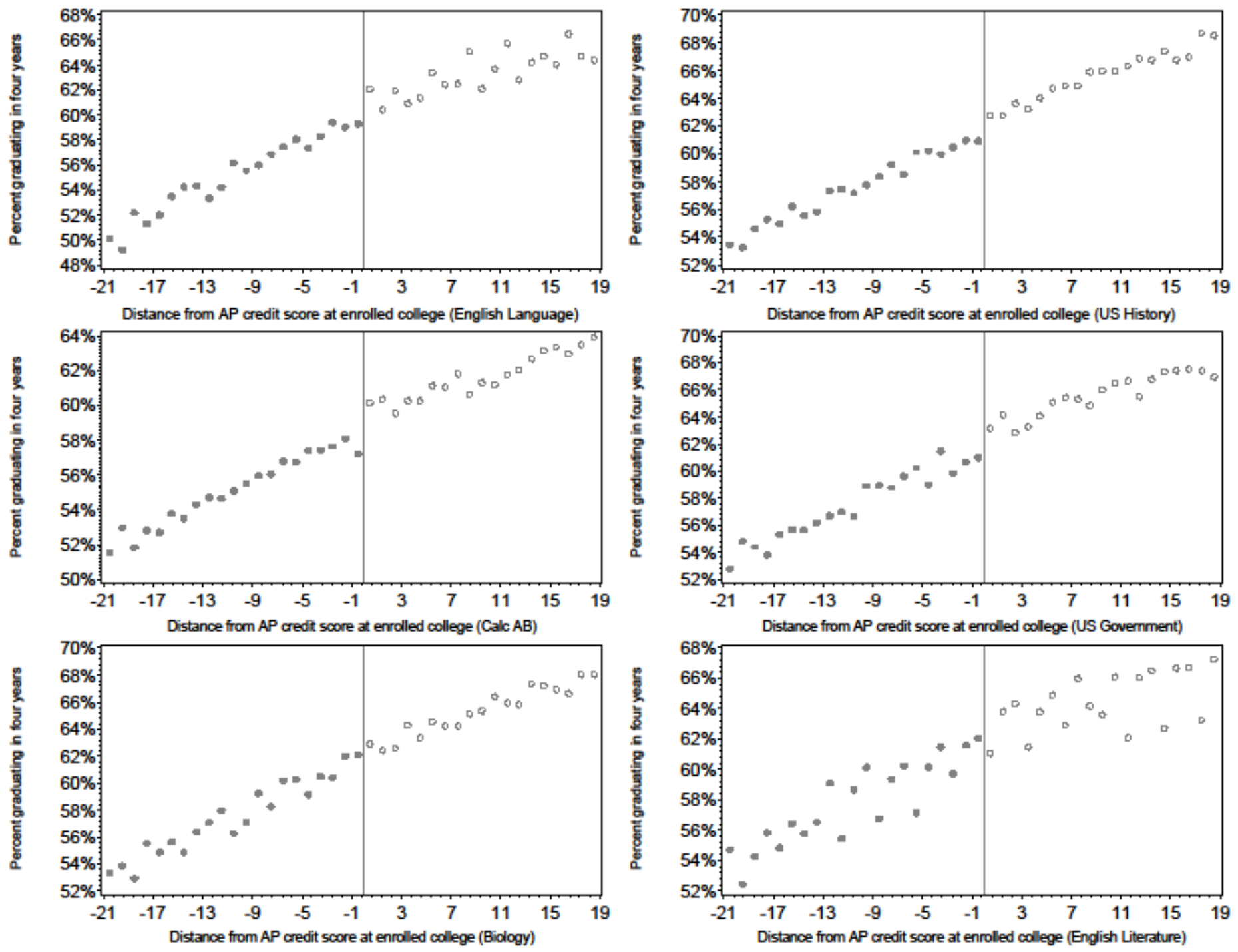
App. Table 1: Distribution of Credit Granting Scores and Test Timing Among On-time Four-Year College-Enrollees

Pct

\begin{tabular}{|c|c|c|c|c|c|c|c|c|c|c|c|}
\hline \multirow[t]{2}{*}{ AP subject } & \multirow[t]{2}{*}{ Total obs. } & \multirow[t]{2}{*}{$\begin{array}{c}\text { Pct. } \\
\text { attending 4- } \\
\text { yr colleges } \\
\text { on-time }\end{array}$} & $\begin{array}{l}\text { enrolling } \\
\text { at colleges } \\
\text { with credit- } \\
\text { granting } \\
\text { policies }\end{array}$ & \multicolumn{4}{|c|}{$\begin{array}{l}\text { Percent distribution of } \\
\text { minimum credit- } \\
\text { granting AP scores }\end{array}$} & \multicolumn{4}{|c|}{$\begin{array}{l}\text { Percent distribution of high } \\
\text { school years during which exam } \\
\text { was taken }\end{array}$} \\
\hline & & & & 2 & 3 & 4 & 5 & Fresh. & Soph. & Jun. & Sen. \\
\hline Studio Art 3-D & 10,622 & 61.8 & $34.4^{-}$ & 0.0 & 61.2 & 31.1 & 7.7 & 0.0 & 0.9 & 10.5 & 88.5 \\
\hline Art History & 94,143 & 75.2 & 90.2 & 0.0 & 55.9 & 35.7 & 8.4 & 0.1 & 6.3 & 27.6 & 66.0 \\
\hline Studio Art 2-D & 62,215 & 61.7 & 38.3 & 0.0 & 59.3 & 33.0 & 7.7 & 0.0 & 0.9 & 11.8 & 87.2 \\
\hline Studio Art Drawing & 61,579 & 61.6 & 72.8 & 0.0 & 60.3 & 34.0 & 5.7 & 0.0 & 1.1 & 14.2 & 84.7 \\
\hline Biology & 690,772 & 80.2 & 95.8 & 0.1 & 55.1 & 39.4 & 5.3 & 0.4 & 6.4 & 34.4 & 58.8 \\
\hline Calculus AB & $1,120,442$ & 81.2 & 95.8 & 1.5 & 65.1 & 30.7 & 2.8 & 0.0 & 0.8 & 14.8 & 84.4 \\
\hline Calculus BC & 330,823 & 86.0 & 95.5 & 6.3 & 60.7 & 28.5 & 4.6 & 0.1 & 1.2 & 18.0 & 80.7 \\
\hline Chemistry & 444,396 & 81.4 & 95.2 & 0.0 & 56.2 & 38.1 & 5.7 & 0.0 & 4.1 & 48.5 & 47.3 \\
\hline Chinese & 7,382 & 60.0 & & & & & & 0.0 & 4.2 & 35.5 & 60.3 \\
\hline Computer Science A & 72,446 & 75.2 & 83.7 & 0.0 & 50.6 & 40.9 & 8.5 & 0.6 & 11.6 & 35.9 & 51.9 \\
\hline Computer Science $A B$ & 25,564 & 81.4 & 90.0 & 1.4 & 44.0 & 49.5 & 5.2 & 0.3 & 8.8 & 36.0 & 54.8 \\
\hline Macroeconomics & 313,155 & 80.2 & 91.9 & 0.0 & 49.8 & 42.6 & 7.6 & 0.0 & 0.7 & 7.8 & 91.5 \\
\hline Microeconomics & 192,262 & 80.9 & 91.0 & 0.0 & 52.5 & 41.3 & 6.1 & 0.1 & 1.3 & 10.2 & 88.4 \\
\hline English Language \& Comp. & $1,228,818$ & 76.0 & 93.3 & 0.0 & 60.3 & 34.9 & 4.8 & 0.0 & 1.0 & 79.5 & 19.5 \\
\hline English Literature \& Comp. & $1,641,172$ & 78.7 & 94.9 & 0.0 & 53.3 & 39.2 & 7.5 & 0.0 & 0.1 & 5.9 & 94.0 \\
\hline Environmental Science & 257,417 & 77.5 & 71.6 & 0.0 & 56.6 & 41.5 & 1.8 & 0.4 & 2.3 & 28.4 & 68.9 \\
\hline European History & 406,442 & 79.4 & 94.5 & 0.0 & 49.3 & 47.0 & 3.7 & 0.3 & 42.3 & 16.7 & 40.8 \\
\hline French Literature & 10,142 & 75.6 & 86.2 & 1.2 & 34.8 & 53.3 & 10.7 & 0.2 & 3.3 & 20.5 & 76.0 \\
\hline French Language and Culture & 106,032 & 75.1 & 92.1 & 1.7 & 50.9 & 43.0 & 4.4 & 0.5 & 3.3 & 23.8 & 72.4 \\
\hline German Language and Culture & 24,368 & 73.2 & 94.4 & 2.8 & 61.1 & 32.9 & 3.2 & 0.8 & 4.3 & 20.9 & 74.0 \\
\hline Comparative Gov.and Politics & 74,051 & 80.5 & 84.6 & 0.0 & 52.2 & 43.9 & 3.9 & 0.1 & 5.1 & 14.1 & 80.7 \\
\hline US Gov and Politics & 847,245 & 79.5 & 91.6 & 0.0 & 61.6 & 36.4 & 2.0 & 0.2 & 3.2 & 8.5 & 88.2 \\
\hline Human Geography & 80,677 & 74.9 & 50.7 & 0.0 & 76.6 & 21.5 & 1.9 & 17.9 & 17.9 & 18.9 & 45.3 \\
\hline Italian Language and Culture & 6,467 & 78.9 & & & & & & 0.1 & 0.9 & 11.1 & 87.9 \\
\hline Japanese Lang. and Culture & 3,949 & 64.7 & & & & & & 0.0 & 2.1 & 20.1 & 77.9 \\
\hline Latin Literature & 18,154 & 86.3 & 77.3 & 1.9 & 38.5 & 51.6 & 8.1 & 0.1 & 3.5 & 37.6 & 58.7 \\
\hline Latin Vergil & 24,040 & 86.7 & 82.8 & 1.5 & 41.1 & 51.2 & 6.3 & 0.2 & 5.2 & 37.4 & 57.3 \\
\hline Music Theory & 52,425 & 75.8 & 78.6 & 0.5 & 66.6 & 29.0 & 3.8 & 0.3 & 5.4 & 28.1 & 66.2 \\
\hline Physics B & 276,199 & 80.9 & 89.7 & 0.0 & 56.3 & 34.7 & 9.0 & 0.1 & 1.4 & 31.4 & 67.1 \\
\hline Physics C: E\&M & 63,715 & 84.5 & 90.4 & 0.0 & 30.7 & 48.4 & 21.0 & 0.0 & 0.6 & 8.8 & 90.5 \\
\hline Physics C: Mechanics & 142,707 & 83.8 & 93.8 & 0.0 & 38.3 & 48.3 & 13.4 & 0.0 & 0.5 & 10.8 & 88.7 \\
\hline Psychology & 510,673 & 75.9 & 92.6 & 0.0 & 58.2 & 40.1 & 1.7 & 0.0 & 1.7 & 26.5 & 71.8 \\
\hline Spanish Language & 472,437 & 61.4 & 93.8 & 1.3 & 63.9 & 29.3 & 5.5 & 1.3 & 8.8 & 33.8 & 56.1 \\
\hline Spanish Literature & 76,242 & 50.1 & 86.5 & 0.1 & 62.3 & 32.0 & 5.6 & 0.4 & 4.8 & 26.5 & 68.2 \\
\hline Statistics & 436,090 & 81.7 & 76.6 & 0.0 & 62.6 & 34.9 & 2.5 & 0.1 & 2.3 & 15.6 & 82.0 \\
\hline US History & $1,438,063$ & 77.9 & 94.8 & 0.0 & 52.7 & 44.3 & 3.0 & 0.0 & 5.9 & 86.8 & 7.3 \\
\hline World History & 305,650 & 74.8 & 47.0 & 0.0 & 50.7 & 46.9 & 2.4 & 2.7 & 73.5 & 13.3 & 10.5 \\
\hline
\end{tabular}

Notes: Includes AP exams taken by the 2004-2009 cohorts. On-time students are those who began at a four-year college within 180 days of HS

graduation. In very rare instances, colleges indicated awarding credit for scores of 1 . These cases are eliminated from our analyses. 
Appendix Table 2: RD Impacts on Bachelor's Attainment within 3 Years

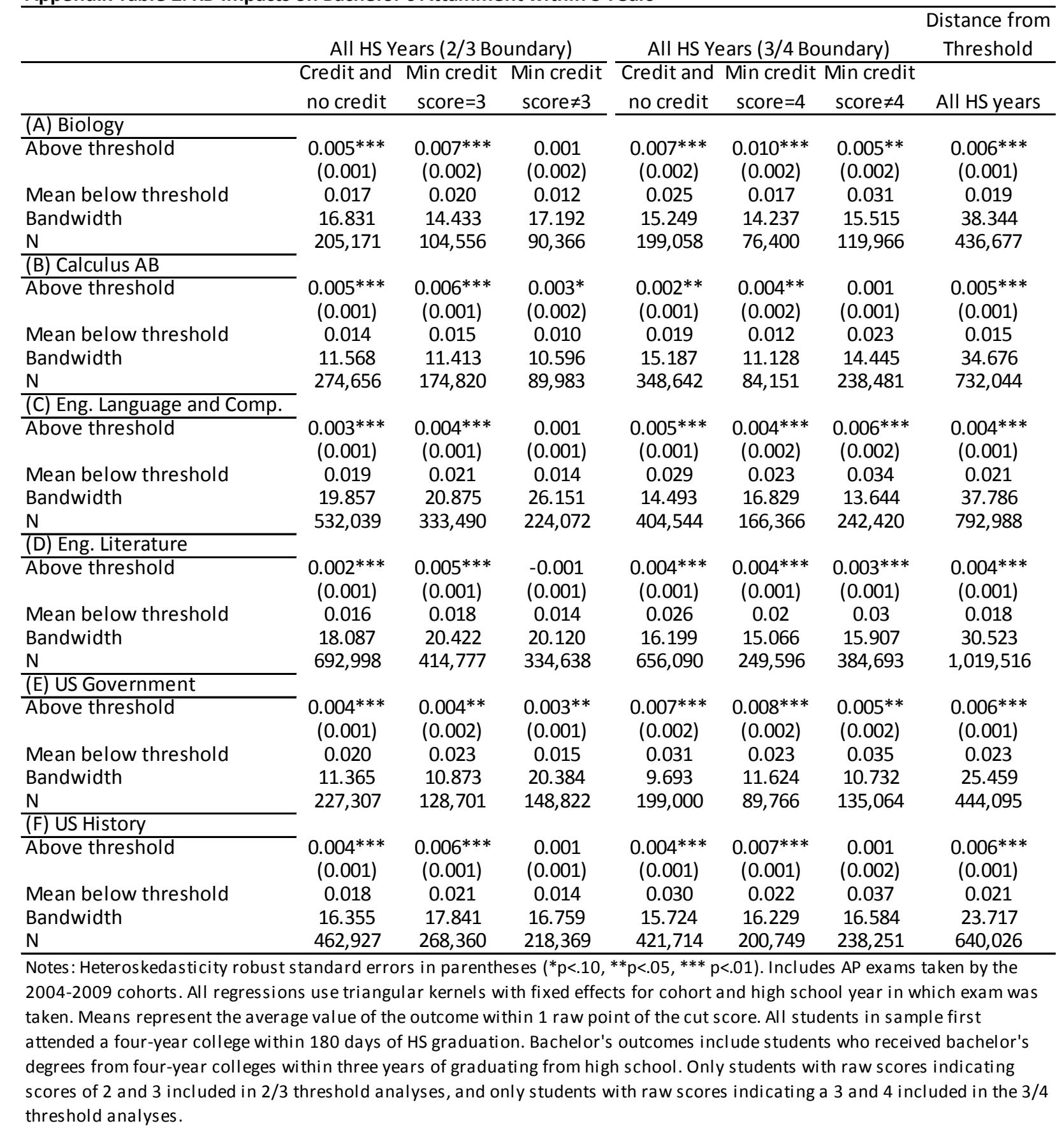


Appendix Table 3: RD Impacts on Bachelor's Attainment with 5 Years

\begin{tabular}{|c|c|c|c|c|c|c|c|}
\hline & \multicolumn{7}{|r|}{ Distance from } \\
\hline & \multicolumn{3}{|c|}{ All HS Years (2/3 Boundary) } & \multicolumn{3}{|c|}{ All HS Years (3/4 Boundary) } & \multirow{2}{*}{$\begin{array}{l}\text { Threshold } \\
\text { All HS years }\end{array}$} \\
\hline & $\begin{array}{c}\text { Credit and } \\
\text { no credit }\end{array}$ & $\begin{array}{c}\text { Min credit } \\
\text { score }=3\end{array}$ & $\begin{array}{c}\text { Min credit } \\
\text { score } \neq 3\end{array}$ & $\begin{array}{c}\text { Min credit } \\
\text { score }=4\end{array}$ & $\begin{array}{c}\text { Min credit } \\
\text { score } \neq 4\end{array}$ & $\begin{array}{c}\text { No } \\
\text { Credit }\end{array}$ & \\
\hline \multicolumn{8}{|l|}{ (A) Biology } \\
\hline Above threshold & $\begin{array}{c}0.002 \\
(0.004)\end{array}$ & $\begin{array}{c}0.000 \\
(0.005)\end{array}$ & $\begin{array}{c}0.004 \\
(0.007)\end{array}$ & $\begin{array}{c}0.002 \\
(0.004)\end{array}$ & $\begin{array}{r}-0.010 \\
(0.007)\end{array}$ & $\begin{array}{c}0.010 * \\
(0.005)\end{array}$ & $\begin{array}{r}-0.003 \\
(0.003)\end{array}$ \\
\hline Mean below threshold & 0.76 & 0.73 & 0.80 & 0.81 & 0.84 & 0.78 & 0.79 \\
\hline Bandwidth & 20.582 & 24.334 & 15.499 & 15.149 & 11.644 & 18.308 & 33.343 \\
\hline $\mathrm{N}$ & 184,442 & 109,675 & 67,765 & 159,275 & 50,821 & 109,749 & 315,983 \\
\hline \multicolumn{8}{|l|}{ (B) Calculus AB } \\
\hline Above threshold & $\begin{array}{l}0.006 * \\
(0.003)\end{array}$ & $\begin{array}{c}0.007 \\
(0.005)\end{array}$ & $\begin{array}{c}0.005 \\
(0.006)\end{array}$ & $\begin{array}{c}0.005 \\
(0.003)\end{array}$ & $\begin{array}{c}0.018 * * * \\
(0.006)\end{array}$ & $\begin{array}{r}-0.000 \\
(0.004)\end{array}$ & $\begin{array}{c}0.007^{* * *} \\
(0.003)\end{array}$ \\
\hline Mean below threshold & 0.76 & 0.73 & 0.81 & 0.80 & 0.83 & 0.79 & 0.77 \\
\hline Bandwidth & 15.841 & 13.215 & 10.939 & 15.475 & 11.548 & 43.151 & 25.925 \\
\hline $\mathrm{N}$ & 258,812 & 158,557 & 75,371 & 285,000 & 70,182 & 203,218 & 469,088 \\
\hline \multicolumn{8}{|l|}{ (C) Eng. Language and Comp. } \\
\hline Above threshold & $\begin{array}{c}0.004 \\
(0.003)\end{array}$ & $\begin{array}{c}0.006^{*} \\
(0.004)\end{array}$ & $\begin{array}{c}0.001 \\
(0.004)\end{array}$ & $\begin{array}{c}-0.002 \\
(0.003)\end{array}$ & $\begin{array}{r}-0.004 \\
(0.004)\end{array}$ & $\begin{array}{r}-0.001 \\
(0.004)\end{array}$ & $\begin{array}{c}0.004 \\
(0.003)\end{array}$ \\
\hline Mean below threshold & 0.75 & 0.72 & 0.80 & 0.83 & 0.87 & 0.80 & 0.78 \\
\hline Bandwidth & 21.755 & 22.895 & 19.689 & 19.345 & 20.358 & 17.546 & 19.852 \\
\hline $\mathrm{N}$ & 427,792 & 264,390 & 160,884 & 372,787 & 137,572 & 223,412 & 418,748 \\
\hline \multicolumn{8}{|l|}{ (D) Eng. Literature } \\
\hline Above threshold & $\begin{array}{c}0.000 \\
(0.002)\end{array}$ & $\begin{array}{c}0.004 \\
(0.003)\end{array}$ & $\begin{array}{c}-0.004 \\
(0.003)\end{array}$ & $\begin{array}{c}0.005^{* *} \\
(0.003)\end{array}$ & $\begin{array}{c}0.007^{* *} \\
(0.004)\end{array}$ & $\begin{array}{c}0.004 \\
(0.003)\end{array}$ & $\begin{array}{c}0.005^{* *} \\
(0.002)\end{array}$ \\
\hline Mean below threshold & 0.75 & 0.72 & 0.79 & 0.82 & 0.86 & 0.80 & 0.79 \\
\hline Bandwidth & 19.021 & 22.983 & 19.651 & 11.962 & 12.688 & 13.195 & 14.503 \\
\hline $\mathrm{N}$ & 588,285 & 350,912 & 270,215 & 405,555 & 177,822 & 263,723 & 492,789 \\
\hline \multicolumn{8}{|l|}{ (E) US Government } \\
\hline Above threshold & $\begin{array}{l}0.008^{* *} \\
(0.004)\end{array}$ & $\begin{array}{l}0.011^{* *} \\
(0.005)\end{array}$ & $\begin{array}{c}0.003 \\
(0.005)\end{array}$ & $\begin{array}{c}0.001 \\
(0.004)\end{array}$ & $\begin{array}{c}0.005 \\
(0.004)\end{array}$ & $\begin{array}{c}-0.002 \\
(0.005)\end{array}$ & $\begin{array}{c}0.008 * * \\
(0.003)\end{array}$ \\
\hline Mean below threshold & 0.76 & 0.73 & 0.81 & 0.83 & 0.86 & 0.81 & 0.79 \\
\hline Bandwidth & 14.358 & 13.900 & 19.311 & 12.293 & 18.388 & 11.759 & 21.668 \\
\hline $\mathrm{N}$ & 226,680 & 128,528 & 118,716 & 193,750 & 96,035 & 114,974 & 312,942 \\
\hline \multicolumn{8}{|l|}{ (F) US History } \\
\hline Above threshold & $\begin{array}{c}-0.002 \\
(0.003)\end{array}$ & $\begin{array}{c}-0.001 \\
(0.004)\end{array}$ & $\begin{array}{c}-0.004 \\
(0.004)\end{array}$ & $\begin{array}{c}0.005^{*} \\
(0.003)\end{array}$ & $\begin{array}{c}0.006 \\
(0.004)\end{array}$ & $\begin{array}{c}0.003 \\
(0.004)\end{array}$ & $\begin{array}{c}0.001 \\
(0.002)\end{array}$ \\
\hline Mean below threshold & 0.76 & 0.71 & 0.81 & 0.83 & 0.87 & 0.79 & 0.79 \\
\hline Bandwidth & 18.193 & 25.763 & 17.428 & 19.752 & 14.293 & 22.614 & 32.632 \\
\hline $\mathrm{N}$ & 390,852 & 234,690 & 174,991 & 387,766 & 140,282 & 214,630 & 627,767 \\
\hline $\begin{array}{l}\text { Notes: Heteroskedasticity robust } \\
2004-2009 \text { cohorts. All regressio } \\
\text { was taken. Means represent the a } \\
\text { attended a four-year college with } \\
\text { bachelor's degrees from four-yea } \\
\text { indicating scores of } 2 \text { and } 3 \text { inclu }\end{array}$ & $\begin{array}{l}\text { standard erro } \\
\text { ns use triangu } \\
\text { verage value } \\
\text { in } 180 \text { days o } \\
r \text { colleges wit } \\
\text { ded in } 2 / 3 \text { th }\end{array}$ & $\begin{array}{l}\text { ula in paren } \\
\text { of kernels } \\
\text { of the outcc } \\
\mathrm{f} \mathrm{HS} \text { gradua } \\
\text { hin five yea } \\
\text { reshold ana }\end{array}$ & $\begin{array}{l}\text { ses }\left({ }^{*} p<.10,\right. \\
\text { th fixed effec } \\
\text { within } 1 \text { ra } \\
\text { n. Bachelor's } \\
\text { f graduatin } \\
\text { es, and only }\end{array}$ & $\begin{array}{l}* * \mathrm{p}<.05, * * * \mathrm{p} \\
\text { ts for cohort } \\
w \text { point of the } \\
\text { outcomes in } \\
\text { from high sc } \\
\text { students witl }\end{array}$ & $\begin{array}{l}<<.01) \text {. Includ } \\
\text { and high sch } \\
\text { cut score. All } \\
\text { clude student } \\
\text { hool. Only st } \\
\text { h raw scores }\end{array}$ & $\begin{array}{l}\text { les AP exa } \\
\text { ool year } \\
\text { I student } \\
\text { ts who re } \\
\text { tudents w } \\
\text { indicatin }\end{array}$ & $\begin{array}{l}\text { S taken by the } \\
\text { which exam } \\
\text { n sample first } \\
\text { ived } \\
\text { raw scores } \\
\text { a } 3 \text { and } 4\end{array}$ \\
\hline
\end{tabular}


Appendix Table 4: RD Estimates of College-Going, College-Choice and Bachelor's Attainment at the $1 / 2$ and $4 / 5$ Boundaries

\begin{tabular}{|c|c|c|c|c|c|c|}
\hline & \multicolumn{2}{|c|}{$\begin{array}{c}\text { Average SAT Scores of } \\
\text { First Colleges }\end{array}$} & \multicolumn{2}{|c|}{$\begin{array}{c}\text { Bachelor's } \\
\text { Attainment within } 4 \\
\text { Years }\end{array}$} & \multicolumn{2}{|c|}{$\begin{array}{c}\text { Bachelor's } \\
\text { Attainment within } 6 \\
\text { Years }\end{array}$} \\
\hline & $(1 / 2)$ & $(4 / 5)$ & $(1 / 2)$ & $(4 / 5)$ & $(1 / 2)$ & $(4 / 5)$ \\
\hline & Boundary & Boundary & Boundary & Boundary & Boundary & Boundary \\
\hline & $\begin{array}{l}\text { Credit and } \\
\text { no credit }\end{array}$ & $\begin{array}{c}\text { Credit and } \\
\text { no credit }\end{array}$ & $\begin{array}{c}\text { Credit and } \\
\text { no credit }\end{array}$ & $\begin{array}{c}\text { Credit and } \\
\text { no credit }\end{array}$ & $\begin{array}{l}\text { Credit and } \\
\text { no credit }\end{array}$ & $\begin{array}{l}\text { Credit } \\
\text { and no }\end{array}$ \\
\hline (A) Biology & & & & & & \\
\hline Above threshold & $\begin{array}{l}-0.325 \\
(1.268)\end{array}$ & $\begin{array}{c}0.906 \\
(1.095)\end{array}$ & $\begin{array}{l}-0.010 * \\
(0.006)\end{array}$ & $\begin{array}{c}0.000 \\
(0.004)\end{array}$ & $\begin{array}{l}-0.009 \\
(0.007)\end{array}$ & $\begin{array}{c}0.003 \\
(0.005)\end{array}$ \\
\hline Mean below threshold & 1129.766 & 1248.000 & 0.493 & 0.725 & 0.741 & 0.886 \\
\hline Bandwidth & 15.124 & 23.365 & 15.178 & 23.364 & 17.238 & 13.921 \\
\hline$\frac{\mathrm{N}}{\text { (B) Calculus AB }}$ & 135,627 & 197,672 & 140,266 & 201,051 & 84,179 & 86,535 \\
\hline Above threshold & $\begin{array}{c}0.077 \\
(1.202)\end{array}$ & $\begin{array}{c}0.558 \\
(0.880)\end{array}$ & $\begin{array}{l}-0.002 \\
(0.005)\end{array}$ & $\begin{array}{c}0.002 \\
(0.004)\end{array}$ & $\begin{array}{l}-0.008 * \\
(0.004)\end{array}$ & $\begin{array}{l}-0.000 \\
(0.003)\end{array}$ \\
\hline Mean below threshold & $1,156.88$ & $1,225.59$ & 0.516 & 0.662 & 0.788 & 0.864 \\
\hline Bandwidth & 8.112 & 16.189 & 10.891 & 15.450 & 13.703 & 21.099 \\
\hline $\begin{array}{l}\mathrm{N} \\
\text { (C) Eng. Language and Comp. }\end{array}$ & 166,507 & 315,754 & 228,541 & 313,577 & 173,018 & 215,460 \\
\hline Above threshold & $\begin{array}{c}0.310 \\
(1.378)\end{array}$ & $\begin{array}{c}1.295 \\
(1.316)\end{array}$ & $\begin{array}{l}-0.006 \\
(0.006)\end{array}$ & $\begin{array}{c}0.004 \\
(0.004)\end{array}$ & $\begin{array}{l}-0.001 \\
(0.007)\end{array}$ & $\begin{array}{c}0.002 \\
(0.004)\end{array}$ \\
\hline Mean below threshold & 1080.171 & 1257.172 & 0.330 & 0.748 & 0.646 & 0.893 \\
\hline Bandwidth & 12.666 & 10.176 & 11.704 & 14.843 & 16.120 & 16.293 \\
\hline$\frac{\mathrm{N}}{\text { (D) Eng. Lit }}$ & 127,379 & 166,026 & 122,832 & 246,362 & 98,469 & 135,110 \\
\hline$\frac{\text { (D) Eng. Literature }}{\text { Above threshold }}$ & $\begin{array}{c}3.334^{* * *} \\
(1.170)\end{array}$ & $\begin{array}{l}1.562^{*} \\
(0.848)\end{array}$ & $\begin{array}{c}0.000 \\
(0.005)\end{array}$ & $\begin{array}{c}0.001 \\
(0.003)\end{array}$ & $\begin{array}{c}0.001 \\
(0.007)\end{array}$ & $\begin{array}{l}0.006 * * \\
(0.003)\end{array}$ \\
\hline Mean below threshold & $1,079.37$ & $1,259.10$ & 0.312 & 0.77 & 0.642 & 0.885 \\
\hline Bandwidth & 16.754 & 22.527 & 12.379 & 14.176 & 13.686 & 19.104 \\
\hline$\frac{\mathrm{N}}{\text { (E) US Government }}$ & 206,672 & 388,802 & 152,294 & 315,296 & 103,862 & 248,215 \\
\hline Above threshold & $\begin{array}{c}1.297 \\
(1.111)\end{array}$ & $\begin{array}{c}1.994 \\
(1.579)\end{array}$ & $\begin{array}{c}0.004 \\
(0.005)\end{array}$ & $\begin{array}{l}-0.005 \\
(0.006)\end{array}$ & $\begin{array}{l}-0.002 \\
(0.005)\end{array}$ & $\begin{array}{c}0.014^{* * *} \\
(0.004)\end{array}$ \\
\hline Mean below threshold & $1,120.65$ & 1251.585 & 0.428 & 0.750 & 0.706 & 0.888 \\
\hline Bandwidth & 17.026 & 8.047 & 18.423 & 8.285 & 35.505 & 16.146 \\
\hline$\frac{\mathrm{N}}{\text { (F) US History }}$ & 183,396 & 106,236 & 204,833 & 110,958 & 172,641 & 106,014 \\
\hline Above threshold & $\begin{array}{l}-0.661 \\
(0.817)\end{array}$ & $\begin{array}{l}2.090^{*} \\
(1.174)\end{array}$ & $\begin{array}{l}-0.002 \\
(0.003)\end{array}$ & $\begin{array}{c}0.004 \\
(0.003)\end{array}$ & $\begin{array}{l}-0.002 \\
(0.004)\end{array}$ & $\begin{array}{l}-0.004 \\
(0.003)\end{array}$ \\
\hline Mean below threshold & 1120.396 & 1261.303 & 0.450 & 0.755 & 0.721 & 0.904 \\
\hline Bandwidth & 16.805 & 13.106 & 24.433 & 27.016 & 21.317 & 21.049 \\
\hline $\mathrm{N}$ & 319,261 & 205,587 & 443,264 & 362,216 & 227,993 & 192,674 \\
\hline $\begin{array}{l}\text { Notes: Heteroskedasticity robust s } \\
\text { exams taken by the } 2004-2009 \text { col } \\
\text { high school year in which exam w } \\
\text { point of the cut score. Only studer } \\
\text { analyses, and only students with } \\
\text { condition on first attending a four } \\
\text { level SAT and bachelor's completi }\end{array}$ & $\begin{array}{l}\text { standard erro } \\
\text { horts. All regr } \\
\text { vas taken. Mea } \\
\text { nts with raw s } \\
\text { raw scores in } \\
\text { r-year college } \\
\text { on are the ou }\end{array}$ & $\begin{array}{l}\text { s in parent } \\
\text { ssions use } \\
\text { ns represer } \\
\text { ores indic } \\
\text { licating a } 4 \\
\text { within } 180\end{array}$ & $\begin{array}{l}\text { s }\left({ }^{*} p<.10,\right. \\
\text { ingular ker } \\
\text { e average } \\
\text { g scores of } \\
5 \text { include } \\
\text { s of HS gra }\end{array}$ & $\begin{array}{l}{ }^{\mathrm{p}}<.05, \\
\text { els with fix } \\
\text { lue of the } \\
\text { and } 2 \text { inc } \\
\text { in the } 4 / 5\end{array}$ & $\begin{array}{l}\text { l.01). Inclu } \\
\text { effects for } \\
\text { tcome with } \\
\text { led in } 1 / 2 \\
\text { eshold an }\end{array}$ & $\begin{array}{l}\text { es AP } \\
\text { cohort and } \\
\text { n } 1 \text { raw } \\
\text { reshold } \\
\text { lyses. We }\end{array}$ \\
\hline
\end{tabular}


Appendix Table 5 - Robustness Tests, Treatment-on-the-Treated, (All estimates are of the coefficient on Above Threshold)

\begin{tabular}{|c|c|c|c|c|c|c|c|c|c|}
\hline & \multicolumn{2}{|c|}{ Rectangular Kernel } & \multicolumn{2}{|c|}{ Triangular Kernel } & & \multicolumn{2}{|c|}{ "Rectangular Kernel } & \multicolumn{2}{|c|}{ Triangular Kernel } \\
\hline & $\begin{array}{c}\text { (1) } \\
\text { BA in } \\
4 \text { Years }\end{array}$ & $\begin{array}{c}\text { (3) } \\
\text { BA in } \\
6 \text { Years }\end{array}$ & $\begin{array}{c}(3) \\
\text { BA in } \\
4 \text { Years }\end{array}$ & $\begin{array}{c}(4) \\
\text { BA in } \\
6 \text { Years }\end{array}$ & & $\begin{array}{c}(5) \\
\text { BA in } \\
4 \text { Years }\end{array}$ & $\begin{array}{c}(6) \\
\text { BA in } \\
6 \text { Years }\end{array}$ & $\begin{array}{c}(7) \\
\text { BA in } \\
4 \text { Years }\end{array}$ & $\begin{array}{c}(8) \\
\text { BA in } \\
6 \text { Years }\end{array}$ \\
\hline (A) Biology & & & & & (D) English Literature & & & & \\
\hline Bandwidth = IK & $\begin{array}{c}0.002 \\
(0.003)\end{array}$ & $\begin{array}{c}-0.008^{* * * *} \\
(0.003)\end{array}$ & $\begin{array}{c}0.002 \\
(0.003)\end{array}$ & $\begin{array}{c}-0.007^{*} \\
(0.003)\end{array}$ & Bandwidth = IK & $\begin{array}{c}0.008 * * * \\
(0.002)\end{array}$ & $\begin{array}{l}0.005^{* *} \\
(0.002)\end{array}$ & $\begin{array}{c}0.007^{* * * *} \\
(0.002)\end{array}$ & $\begin{array}{c}0.007^{* * *} \\
(0.003)\end{array}$ \\
\hline Bandwidth $=\mid \mathrm{K} / 2$ & $\begin{array}{c}0.002 \\
(0.004)\end{array}$ & $\begin{array}{l}-0.007 \\
(0.004)\end{array}$ & $\begin{array}{c}0.002 \\
(0.005)\end{array}$ & $\begin{array}{c}-0.010^{* *} \\
(0.005)\end{array}$ & Bandwidth $=I \mathrm{~K} / 2$ & $\begin{array}{c}0.005 \\
(0.003)\end{array}$ & $\begin{array}{c}0.009 * * * \\
(0.003)\end{array}$ & $\begin{array}{c}0.003 \\
(0.003)\end{array}$ & $\begin{array}{l}0.007^{* *} \\
(0.004)\end{array}$ \\
\hline Bandwidth $=1 \mathrm{~K} / 4$ & $\begin{array}{c}0.002 \\
(0.006)\end{array}$ & $\begin{array}{c}-0.013 * * \\
(0.006)\end{array}$ & $\begin{array}{c}0.002 \\
(0.006)\end{array}$ & $\begin{array}{c}-0.013^{*} \\
(0.007)\end{array}$ & Bandwidth $=I \mathrm{~K} / 4$ & $\begin{array}{l}-0.004 \\
(0.004)\end{array}$ & $\begin{array}{l}-0.001 \\
(0.005)\end{array}$ & $\begin{array}{c}0.001 \\
(0.005)\end{array}$ & $\begin{array}{c}0.001 \\
(0.005)\end{array}$ \\
\hline Bandwidth $=\mathrm{IK}$, controls & $\begin{array}{c}0.003 \\
(0.003)\end{array}$ & $\begin{array}{c}-0.007^{* *} \\
(0.003)\end{array}$ & $\begin{array}{c}0.003 \\
(0.003)\end{array}$ & $\begin{array}{l}-0.006^{*} \\
(0.003)\end{array}$ & $\begin{array}{l}\text { Bandwidth = IK, controls } \\
\text { (E) US Government }\end{array}$ & $\begin{array}{c}0.008 * * * \\
(0.002)\end{array}$ & $\begin{array}{l}0.004^{*} \\
(0.002)\end{array}$ & $\begin{array}{c}0.007^{* * *} \\
(0.002)\end{array}$ & $\begin{array}{c}0.007^{* * *} \\
(0.003)\end{array}$ \\
\hline Bandwi & $\begin{array}{c}0.012^{* * *} \\
(0.003)\end{array}$ & $\begin{array}{c}0.001 \\
(0.003)\end{array}$ & $\begin{array}{c}0.016^{* * *} \\
(0.003)\end{array}$ & $\begin{array}{c}0.003 \\
(0.003)\end{array}$ & Bandwidth $=I \mathrm{~K}$ & $\begin{array}{c}0.015^{* * *} \\
(0.003)\end{array}$ & $\begin{array}{l}0.005^{*} \\
(0.003)\end{array}$ & $\begin{array}{c}0.015^{* * *} \\
(0.003)\end{array}$ & $\begin{array}{c}0.007^{* *} \\
(0.003)\end{array}$ \\
\hline Bandwidth $=1 \mathrm{~K} / 2$ & $\begin{array}{c}0.016^{* * * *} \\
(0.004)\end{array}$ & $\begin{array}{c}0.002 \\
(0.004)\end{array}$ & $\begin{array}{c}0.021^{* * *} \\
(0.005)\end{array}$ & $\begin{array}{c}0.003 \\
(0.004)\end{array}$ & Bandwidth $=I \mathrm{~K} / 2$ & $\begin{array}{c}0.014^{* * *} \\
(0.004)\end{array}$ & $\begin{array}{l}0.011^{* *} \\
(0.004)\end{array}$ & $\begin{array}{c}0.016^{* * * *} \\
(0.004)\end{array}$ & $\begin{array}{l}0.011^{* *} \\
(0.005)\end{array}$ \\
\hline Bandwidth $=1 \mathrm{~K} / 4$ & $\begin{array}{c}0.026 * * * \\
(0.006)\end{array}$ & $\begin{array}{c}0.002 \\
(0.005)\end{array}$ & $\begin{array}{c}0.029 * * * \\
(0.007)\end{array}$ & $\begin{array}{c}0.007 \\
(0.005)\end{array}$ & Bandwidth $=1 \mathrm{~K} / 4$ & $\begin{array}{c}0.018 * * * \\
(0.005)\end{array}$ & $\begin{array}{l}0.012^{* *} \\
(0.006)\end{array}$ & $\begin{array}{c}0.020^{* * * *} \\
(0.006)\end{array}$ & $\begin{array}{l}0.015^{* *} \\
(0.007)\end{array}$ \\
\hline Bandwidth $=I \mathrm{~K}$, controls & $\begin{array}{c}0.013^{* * *} \\
(0.003)\end{array}$ & $\begin{array}{c}0.001 \\
(0.002)\end{array}$ & $\begin{array}{c}0.017 * * * \\
(0.003)\end{array}$ & $\begin{array}{c}0.003 \\
(0.003)\end{array}$ & Bandwidth $=\mathrm{IK}$, controls & $\begin{array}{c}0.015^{* * *} \\
(0.003)\end{array}$ & $\begin{array}{c}0.005 \\
(0.003)\end{array}$ & $\begin{array}{c}0.014^{* * *} \\
(0.003)\end{array}$ & $\begin{array}{l}0.006^{*} \\
(0.003)\end{array}$ \\
\hline $\begin{array}{l}\text { (C) English Langu } \\
\text { Composition }\end{array}$ & & & & & (F) US History & & & & \\
\hline Bandwidth $=\mathrm{IK}$ & $\begin{array}{c}0.009 * * * \\
(0.002)\end{array}$ & $\begin{array}{c}0.002 \\
(0.002)\end{array}$ & $\begin{array}{c}0.010 * * * \\
(0.002)\end{array}$ & $\begin{array}{c}0.002 \\
(0.003)\end{array}$ & Bandwidth = IK & $\begin{array}{c}0.009 * * * \\
(0.002)\end{array}$ & $\begin{array}{l}-0.003^{*} \\
(0.002)\end{array}$ & $\begin{array}{c}0.011 * * * \\
(0.002)\end{array}$ & $\begin{array}{l}-0.002 \\
(0.002)\end{array}$ \\
\hline Bandwidth $=1 \mathrm{~K} / 2$ & $\begin{array}{c}0.009 * * * \\
(0.003)\end{array}$ & $\begin{array}{c}0.001 \\
(0.003)\end{array}$ & $\begin{array}{c}0.011^{* * *} \\
(0.003)\end{array}$ & $\begin{array}{c}0.004 \\
(0.004)\end{array}$ & Bandwidth $=1 \mathrm{~K} / 2$ & $\begin{array}{c}0.012 * * * \\
(0.003)\end{array}$ & $\begin{array}{l}-0.000 \\
(0.002)\end{array}$ & $\begin{array}{c}0.011 * * * \\
(0.003)\end{array}$ & $\begin{array}{l}-0.000 \\
(0.003)\end{array}$ \\
\hline Bandwidth $=1 \mathrm{~K} / 4$ & $\begin{array}{c}0.013^{* * *} \\
(0.004)\end{array}$ & $\begin{array}{l}0.008^{*} \\
(0.005)\end{array}$ & $\begin{array}{c}0.017 * * * \\
(0.005)\end{array}$ & $\begin{array}{c}0.010^{* *} \\
(0.005)\end{array}$ & Bandwidth $=1 \mathrm{~K} / 4$ & $\begin{array}{c}0.011 * * * \\
(0.004)\end{array}$ & $\begin{array}{c}0.001 \\
(0.003)\end{array}$ & $\begin{array}{c}0.012^{* * *} \\
(0.004)\end{array}$ & $\begin{array}{c}0.002 \\
(0.003)\end{array}$ \\
\hline Bandwidth $=\mathrm{IK}$, controls & $\begin{array}{c}0.010 * * * \\
(0.002)\end{array}$ & $\begin{array}{c}0.002 \\
(0.002)\end{array}$ & $\begin{array}{c}0.011 * * * \\
(0.002)\end{array}$ & $\begin{array}{c}0.003 \\
(0.003)\end{array}$ & Bandwidth $=1 \mathrm{~K}$, controls & $\begin{array}{c}0.010 * * * \\
(0.002)\end{array}$ & $\begin{array}{l}-0.002 \\
(0.002)\end{array}$ & $\begin{array}{c}0.011 * * * \\
(0.002)\end{array}$ & $\begin{array}{l}-0.001 \\
(0.002)\end{array}$ \\
\hline
\end{tabular}

Note: Heteroskedasticity robust standard errors in parentheses $\left({ }^{*} p<.10,{ }^{* *} p<.05,{ }^{* * *} p<.01\right)$. Includes AP exams taken by the $2004-2009$ cohorts. Only includes students who begin at a four-year institution within 180 days of HS graduation are included. 
Appendix Table 6: RD Impacts on Bachelor's Degree

Completion Within 4 and 6 Years

\begin{tabular}{|c|c|c|c|c|}
\hline & & 4-yr & & \\
\hline AP subject & 4-Yr & (SE) & $6-Y r$ & 6-Yr (SE) \\
\hline Studio Art 3-D & -0.007 & (0.044) & -0.024 & $(0.042)$ \\
\hline Art History & $0.028 * * *$ & $(0.011)$ & 0.010 & (0.011) \\
\hline Studio Art 2-D & -0.022 & $(0.017)$ & 0.016 & (0.019) \\
\hline Studio Art Drawing & $0.042 * * *$ & (0.014) & 0.017 & (0.014) \\
\hline Biology & 0.002 & $(0.003)$ & $-0.007^{*}$ & $(0.003)$ \\
\hline Calculus AB & $0.016 * * *$ & $(0.003)$ & 0.003 & $(0.003)$ \\
\hline Calculus BC & 0.009 & $(0.006)$ & $0.010 * *$ & $(0.005)$ \\
\hline Chemistry & $0.013^{* * *}$ & $(0.004)$ & $0.008^{*}$ & $(0.004)$ \\
\hline Computer Science A & 0.001 & (0.014) & -0.000 & $(0.013)$ \\
\hline Computer Science AB & -0.016 & (0.019) & -0.006 & $(0.016)$ \\
\hline Macroeconomics & 0.004 & $(0.005)$ & $-0.008^{*}$ & $(0.004)$ \\
\hline Microeconomics & $0.013^{* *}$ & $(0.006)$ & -0.000 & $(0.006)$ \\
\hline English Language \& Comp. & $0.010 * * *$ & $(0.002)$ & 0.002 & (0.003) \\
\hline English Literature \& Comp. & $0.007 * * *$ & $(0.002)$ & $0.007 * * *$ & (0.003) \\
\hline Environmental Science & -0.008 & $(0.005)$ & $-0.015^{* *}$ & $(0.005)$ \\
\hline European History & $0.016 * * *$ & (0.004) & $0.008^{*}$ & $(0.004)$ \\
\hline French Literature & 0.005 & $(0.022)$ & 0.017 & $(0.022)$ \\
\hline French Language and Culture & -0.003 & $(0.010)$ & -0.005 & $(0.007)$ \\
\hline German Language and Culture & -0.004 & $(0.021)$ & -0.016 & $(0.016)$ \\
\hline Comparative Gov.and Politics & 0.015 & $(0.010)$ & -0.007 & (0.009) \\
\hline US Gov and Politics & $0.015^{* * *}$ & (0.003) & $0.007^{* *}$ & $(0.003)$ \\
\hline Human Geography & 0.004 & $(0.014)$ & 0.007 & $(0.013)$ \\
\hline Latin Literature & -0.023 & (0.019) & -0.007 & $(0.020)$ \\
\hline Latin Vergil & 0.017 & $(0.015)$ & -0.004 & $(0.014)$ \\
\hline Music Theory & 0.015 & $(0.014)$ & 0.020 & $(0.017)$ \\
\hline Physics B & $0.017^{* * *}$ & $(0.006)$ & 0.003 & $(0.006)$ \\
\hline Physics C: E\&M & 0.019* & $(0.011)$ & $0.016^{*}$ & (0.009) \\
\hline Physics C: Mechanics & 0.004 & $(0.008)$ & -0.004 & $(0.007)$ \\
\hline Psychology & $0.012 * * *$ & $(0.005)$ & $0.008^{* *}$ & (0.004) \\
\hline Spanish Language & -0.004 & $(0.005)$ & 0.005 & (0.005) \\
\hline Spanish Literature & 0.011 & (0.015) & -0.030 & (0.019) \\
\hline Statistics & $0.009 * *$ & (0.004) & $0.008^{*}$ & (0.004) \\
\hline US History & $0.011 * * *$ & $(0.002)$ & -0.002 & $(0.002)$ \\
\hline World History & $0.014^{* *}$ & $(0.006)$ & -0.002 & $(0.008)$ \\
\hline \multicolumn{5}{|c|}{$\begin{array}{l}\text { Notes: Heteroskedasticity robust standard errors in parenthes es }\left({ }^{*} \mathrm{p}<.10,\right. \\
\left.* * \mathrm{p}<.05,{ }^{* * *} \mathrm{p}<.01\right) \text {. Includes AP exams taken by the } 2004-2009 \text { cohorts. }\end{array}$} \\
\hline \multicolumn{5}{|c|}{$\begin{array}{l}\text { Sample includes only students who began at a four-year college within } 180 \\
\text { days of HS graduation. Forcing variable is distance from the college- } \\
\text { specific credit-granting threshold, and a triangular kernel is used in all } \\
\text { regressions. }\end{array}$} \\
\hline
\end{tabular}


Appendix Table 7: Heterogeneous RD Impacts on Bachelor's Attainment within 4 Years

\begin{tabular}{|c|c|c|c|c|c|c|c|c|c|}
\hline & (1) & (2) & (3) & (4) & (5) & (6) & (7) & (8) & (9) \\
\hline & Female & Male & Asian & Black & Hispanic & White & $\begin{array}{c}\text { Parent HS } \\
\text { dropout }\end{array}$ & $\begin{array}{c}\text { Parent HS } \\
\text { graduate }\end{array}$ & $\begin{array}{c}\text { Parent BA } \\
\text { or more }\end{array}$ \\
\hline \multicolumn{10}{|l|}{ (A) Biology } \\
\hline Above threshold & $\begin{array}{l}-0.000 \\
(0.004)\end{array}$ & $\begin{array}{c}0.006 \\
(0.006)\end{array}$ & $\begin{array}{r}-0.004 \\
(0.009)\end{array}$ & $\begin{array}{r}-0.001 \\
(0.016)\end{array}$ & $\begin{array}{l}-0.018 \\
(0.014)\end{array}$ & $\begin{array}{c}0.007^{*} \\
(0.004)\end{array}$ & $\begin{array}{c}0.025^{*} \\
(0.013)\end{array}$ & $\begin{array}{c}0.006 \\
(0.009)\end{array}$ & $\begin{array}{r}-0.005 \\
(0.005)\end{array}$ \\
\hline Mean below threshold & 0.676 & 0.541 & 0.61 & 0.522 & 0.564 & 0.637 & 0.511 & 0.557 & 0.675 \\
\hline Bandwidth & 31.331 & 26.903 & 24.321 & 34.439 & 28.467 & 25.616 & 35.832 & 36.441 & 24.598 \\
\hline $\mathrm{N}$ & 229,025 & 136,685 & 52,930 & 18,418 & 22,949 & 223,318 & 26,372 & 53,489 & 174,086 \\
\hline \multicolumn{10}{|l|}{ (B) Calculcus AB } \\
\hline Above threshold & $\begin{array}{c}0.016^{* * *} \\
(0.004)\end{array}$ & $\begin{array}{c}0.013^{* * *} \\
(0.005)\end{array}$ & $\begin{array}{c}0.009 \\
(0.008)\end{array}$ & $\begin{array}{c}-0.017 \\
(0.015)\end{array}$ & $\begin{array}{c}0.007 \\
(0.011)\end{array}$ & $\begin{array}{c}0.017^{* * *} \\
(0.003)\end{array}$ & $\begin{array}{c}0.003 \\
(0.012)\end{array}$ & $\begin{array}{c}0.024^{* * *} \\
(0.009)\end{array}$ & $\begin{array}{l}0.011^{* *} \\
(0.004)\end{array}$ \\
\hline Mean below threshold & 0.658 & 0.486 & 0.527 & 0.481 & 0.484 & 0.594 & 0.504 & 0.516 & 0.625 \\
\hline Bandwidth & 17.511 & 20.116 & 20.228 & 27.091 & 22.645 & 24.128 & 23.578 & 22.035 & 17.657 \\
\hline $\mathrm{N}$ & 208,913 & 228,590 & 64,903 & 23,860 & 36,557 & 392,611 & 35,737 & 63,647 & 217,717 \\
\hline \multicolumn{10}{|l|}{ (C) English Language and } \\
\hline \multicolumn{10}{|l|}{ Composition } \\
\hline Above threshold & $\begin{array}{c}0.012^{* * *} \\
(0.003)\end{array}$ & $\begin{array}{c}0.006 \\
(0.004)\end{array}$ & $\begin{array}{l}0.013^{*} \\
(0.007)\end{array}$ & $\begin{array}{c}0.021^{*} \\
(0.010)\end{array}$ & $\begin{array}{l}0.019 * * \\
(0.008)\end{array}$ & $\begin{array}{c}0.008^{* * *} \\
(0.003)\end{array}$ & $\begin{array}{c}0.003 \\
(0.009)\end{array}$ & $\begin{array}{c}0.007 \\
(0.006)\end{array}$ & $\begin{array}{c}0.013^{* * *} \\
(0.003)\end{array}$ \\
\hline Mean below threshold & 0.626 & 0.533 & 0.621 & 0.464 & 0.433 & 0.618 & 0.464 & 0.509 & 0.642 \\
\hline Bandwidth & 28.066 & 25.390 & 31.637 & 36.215 & 32.757 & 33.478 & 36.719 & 34.003 & 27.655 \\
\hline $\mathrm{N}$ & 436,483 & 238,358 & 84,518 & 43,348 & 72,528 & 523,912 & 53,487 & 104,721 & 383,090 \\
\hline \multicolumn{10}{|l|}{ (D) English Literature } \\
\hline Above threshold & $\begin{array}{c}0.010^{* * *} \\
(0.003)\end{array}$ & $\begin{array}{c}0.001 \\
(0.004)\end{array}$ & $\begin{array}{c}0.006 \\
(0.006)\end{array}$ & $\begin{array}{c}0.006 \\
(0.009)\end{array}$ & $\begin{array}{c}0.008 \\
(0.007)\end{array}$ & $\begin{array}{c}0.007^{* *} \\
(0.003)\end{array}$ & $\begin{array}{c}0.010 \\
(0.008)\end{array}$ & $\begin{array}{l}-0.002 \\
(0.005)\end{array}$ & $\begin{array}{c}0.010^{* * *} \\
(0.003)\end{array}$ \\
\hline Mean below threshold & 0.646 & 0.576 & 0.619 & 0.503 & 0.502 & 0.643 & 0.534 & 0.544 & 0.673 \\
\hline Bandwidth & 17.932 & 20.274 & 24.975 & 33.090 & 31.190 & 18.482 & 33.988 & 35.448 & 17.212 \\
\hline $\mathrm{N}$ & 460,949 & 282,878 & 96,192 & 55,554 & 83,739 & 539,133 & 67,690 & 142,512 & 379,468 \\
\hline \multicolumn{10}{|l|}{ (E) US Government } \\
\hline Above threshold & $\begin{array}{c}0.015^{* * *} \\
(0.004)\end{array}$ & $\begin{array}{c}0.014^{* * *} \\
(0.005)\end{array}$ & $\begin{array}{c}0.029 * * * \\
(0.009)\end{array}$ & $\begin{array}{c}0.026 * \\
(0.013)\end{array}$ & $\begin{array}{c}0.006 \\
(0.011)\end{array}$ & $\begin{array}{c}0.015^{* * *} \\
(0.004)\end{array}$ & $\begin{array}{c}0.008 \\
(0.012)\end{array}$ & $\begin{array}{c}0.017^{* *} \\
(0.008)\end{array}$ & $\begin{array}{c}0.013^{* * *} \\
(0.004)\end{array}$ \\
\hline Mean below threshold & 0.668 & 0.548 & 0.589 & 0.446 & 0.507 & 0.632 & 0.466 & 0.526 & 0.661 \\
\hline Bandwidth & 26.454 & 24.754 & 24.654 & 40.630 & 27.629 & 23.138 & 28.386 & 33.852 & 25.628 \\
\hline $\mathrm{N}$ & 237,921 & 209,244 & 54,265 & 26,208 & 39,122 & 295,868 & 29,174 & 67,829 & 260,587 \\
\hline \multicolumn{10}{|l|}{ (F) US History } \\
\hline Above threshold & $\begin{array}{c}0.013^{* * *} \\
(0.003)\end{array}$ & $\begin{array}{c}0.009 * * * \\
(0.004)\end{array}$ & $\begin{array}{c}0.008 \\
(0.006)\end{array}$ & $\begin{array}{c}0.028^{* *} \\
(0.011)\end{array}$ & $\begin{array}{l}-0.001 \\
(0.009)\end{array}$ & $\begin{array}{c}0.012^{* * *} \\
(0.003)\end{array}$ & $\begin{array}{r}-0.000 \\
(0.010)\end{array}$ & $\begin{array}{l}0.013^{* *} \\
(0.006)\end{array}$ & $\begin{array}{l}0.007^{* *} \\
(0.003)\end{array}$ \\
\hline Mean below threshold & 0.669 & 0.538 & 0.634 & 0.482 & 0.533 & 0.623 & 0.523 & 0.526 & 0.66 \\
\hline Bandwidth & 31.604 & 28.013 & 33.489 & 37.412 & 28.362 & 25.315 & 32.975 & 39.988 & 27.044 \\
\hline $\mathrm{N}$ & 429,330 & 332,803 & 97,342 & 40,370 & 52,247 & 491,548 & 48,268 & 117,521 & 405,733 \\
\hline
\end{tabular}


Appendix Table 8: RD Impacts on SAT Score Sending among Junior Test Takers

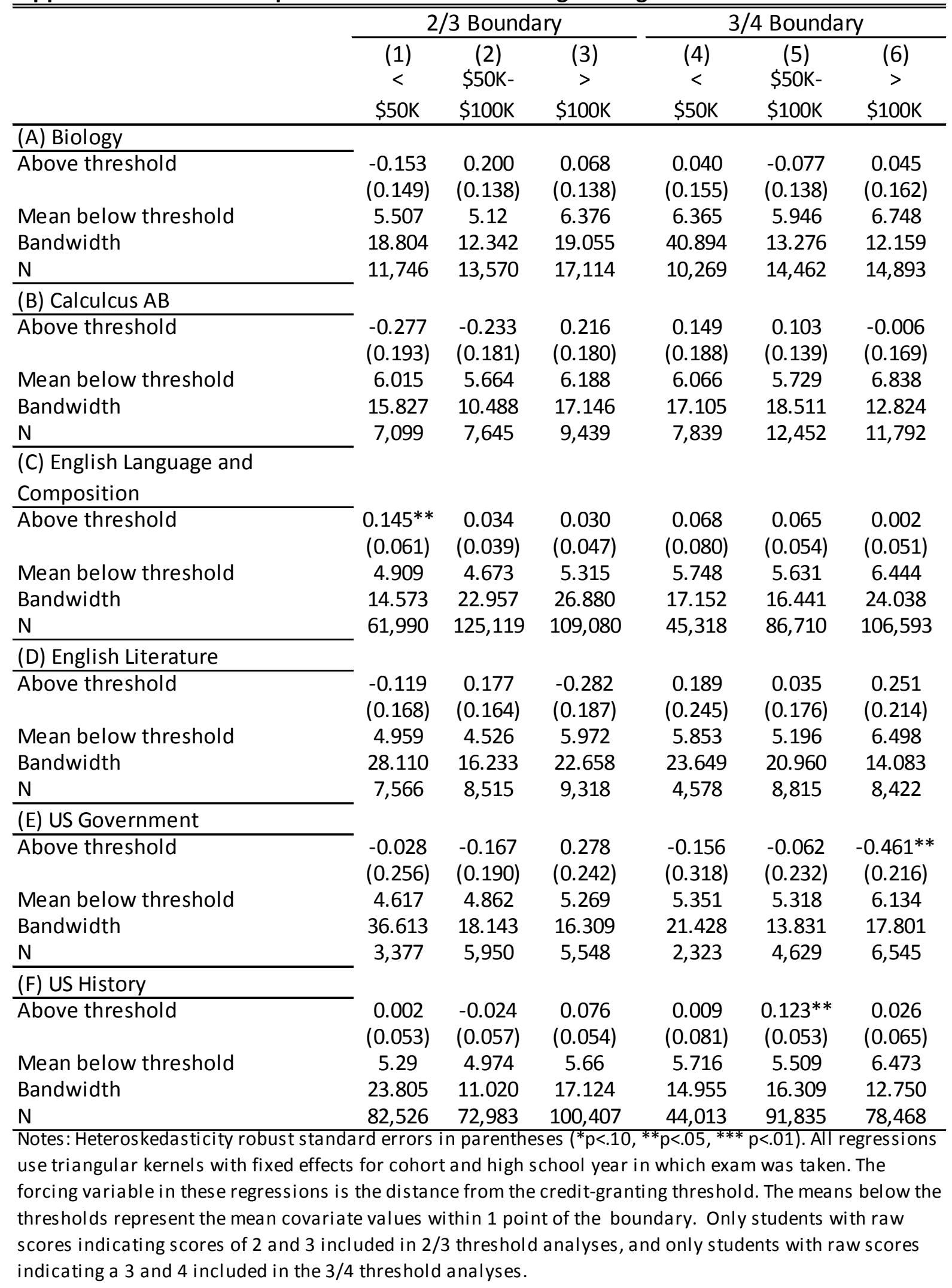

